\title{
To include or not to include: Teachers' social representations of inclusion of students with Asperger syndrome
}

\author{
Ann-Charlotte Linton
}

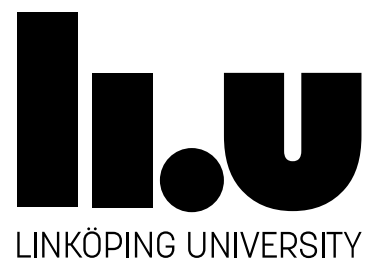

Linköping Studies in Arts and Science No. 656

Studies from the Swedish Institute for Disability Research No.75

Linköping University,

Department of Behavioural Sciences and Learning

Linköping 2015 
Linköping Studies in Arts and Science No. 656

Studies from the Swedish Institute for Disability Research No.75

At the Faculty of Arts and Sciences at Linköping University, research and doctoral studies are carried out within broad problem areas. Research is organized in interdisciplinary research environments and doctoral studies mainly in graduate schools. Jointly, they publish the series Linköping Studies in arts and Science. This thesis comes from The Swedish Institute for Disability Research at the Department of Behavioural Sciences and Learning.

Distributed by:

Department of Behavioural Sciences and Learning

Linköping University

SE-581 83 Linköping

Ann-Charlotte Linton

To include or not to include: Teachers’ social representations of inclusion of students with Asperger syndrome

Edition 1:1

ISBN 978-91-7685-956-8

ISSN 0282-9800

ISSN 1650-1128

(C)Ann-Charlotte Linton, 2015

Department of Behavioural Sciences and Learning

Cover by: Magnus Malmstedt

Printed by: LiU-Tryck, Linköping, 2015

Published article has been reprinted with the permission of the copyright holder. 
For Hugo, Dahlia, Viola and Lucy 


\begin{abstract}
Ann-Charlotte Linton (2015): To include or not to include:

Teachers' social representations of inclusion of students with

Asperger syndrome. Studies from The Swedish Institute for Disability Research 75.
\end{abstract}

Evidence on inclusive classrooms shows that successful implementation of inclusion can lead to increased social involvement, personal well-being and higher levels of academic performance compared with segregated provision. Despite these potential benefits inclusion of students with Asperger syndrome (AS) in the mainstream classroom is problematic. Support from teachers is a key strategy for accommodating students with AS diagnosis in the mainstream classroom. Less well is understood how teachers create an inclusive environment for these learners. Teachers' social representations (SR), have a bearing on how they interact and accommodate, therefore the first aim of this dissertation was to explore teachers' SR of students with AS. The second aim was to highlight the role of contextual factors and prior experience in forming SR. The third aim was to study the link between teachers' individual practice and broader institutional forces by comparing the SRs among principals, school health professionals and teachers. The forth aim was to study what teacher factors predict teachers' positive attitudes towards inclusion of students with AS.

The findings show that a medical approach seems to dominate especially earlier trained teachers' SRs; however, there is a tendency to view the environment increasingly important. Our results suggest that experience with students with AS is related to teachers' SR of these students. In addition, our data indicate that there is a need to bridge the gap between the organizational level, the classroom level and the individual student level in order to reduce barriers for students with AS to fit into an inclusive environment. Finally, positive attitudes towards inclusion of students with AS were found to relate to teachers' knowledge of teaching students with AS and their attitude toward students with AS. To conclude, teachers' SRs are deeply seated and the first step is to bring them to the forefront so that teachers are aware of them. In addition, there is a need for team building in the school arena to achieve a common vision for an inclusive school.

Key words: inclusion, Asperger syndrome, autism spectrum disorder, mainstream teachers, social representations, social representation theory 


\section{List of papers}

This thesis is based on the following papers:

I. Linton, AC., Germundsson, P., Heimann, M., Danermark, B. (2013)Teachers' social representation of students with Asperger diagnosis. European Journal of Special Needs Education 28(4)

II. Linton, AC., Germundsson, P., Heimann, M., Danermark, B. (2015) The role of experience in teachers' social representations of students with ASD (Asperger). Cogent Education 2 (1)

III. Linton, AC., Germundsson, P., Heimann, M., Danermark, B. School staff's social representations of inclusion of students with Autism Spectrum Disorder (Asperger) (submitted)

IV. Linton, AC., Germundsson, P., Heimann, M., Danermark, B. Teachers' attitudes towards inclusion of students with Asperger diagnosis (manuscript) 


\section{TABLE OF CONTENTS}

INTRODUCTION

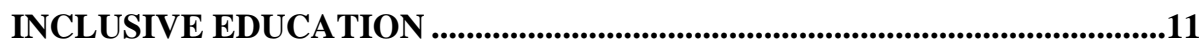

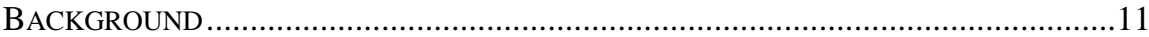

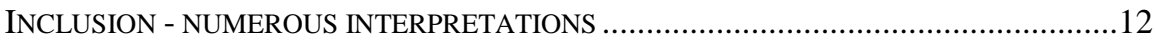

STUDENTS' RIGHTS, ACCESS AND PARTICIPATION ...............................................13

CULTURALLY DEPENDENT DEFINITIONS OF INCLUSION .....................................14

CHALLENGES IN DEFINING THE CONCEPT OF INCLUSION .....................................15

ASPERGER SYNDROME - PART OF AUTISM SPECTRUM DISORDER ..17

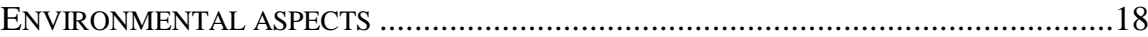

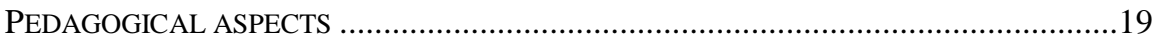

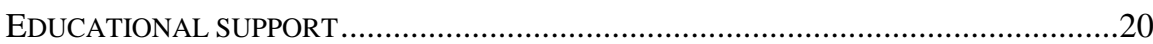

THE PROBLEM OF EXCLUSION: ABSENTEEISM ......................................................20

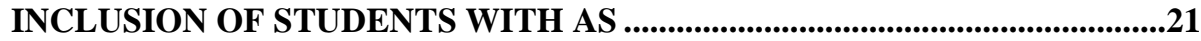

TEACHERS AND INCLUSION OF STUDENTS WITH AS ….......................................22

CRITICISM OF INCLUSION FOR STUDENTS WITH AS ..............................................22

RESEARCH ON INCLUSION OF STUDENTS WITH AS ...........................................23

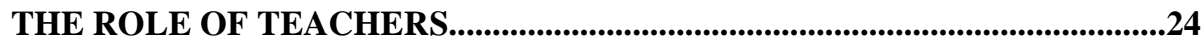

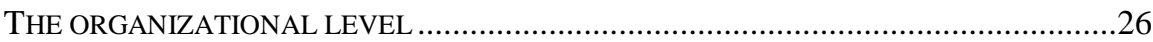

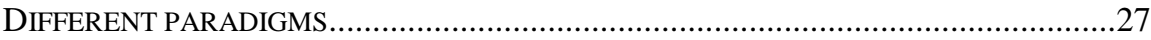

KNOWLEDGE AS A SOCIAL PRODUCT ..................................................28

TEACHERS' SRS - WHERE DO THEY ORIGINATE? ..................................................29

Special needs and the medical model .........................................................29

The psycho-medical paradigm..............................................................29

SOCIAL REPRESENTATION THEORY: HOW IT RELATES TO

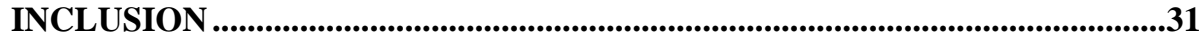

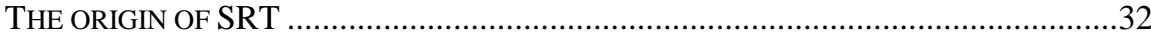

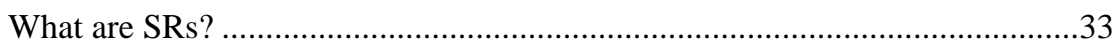


Anchoring and objectifying - mechanisms at work in the construction of the object

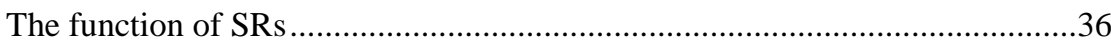

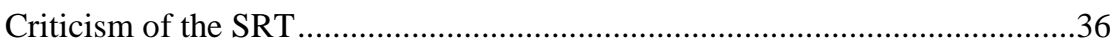

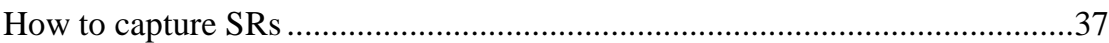

SRs: The central core and the peripheral system ..........................................39

TEACHERS' REPRESENTATIONS OF INCLUSION ....................................41

HOW TO CAPTURE TEACHERS’ SRS OF INCLUSION OF AS ...................................42

AIM

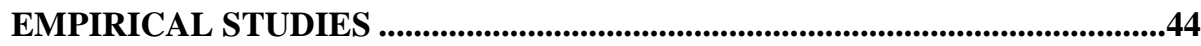

METHODOLOGICAL CHOICES ........................................................................4

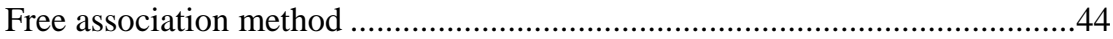

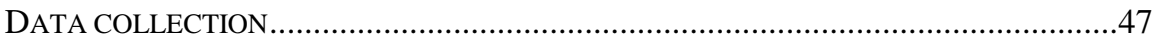

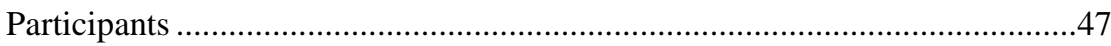

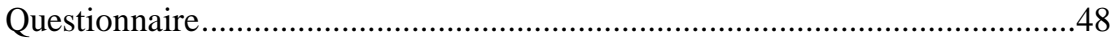

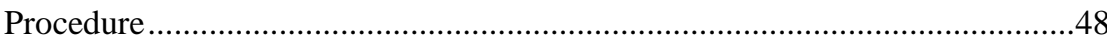

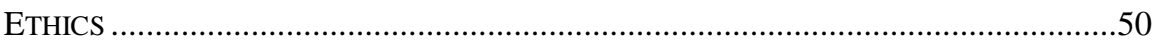

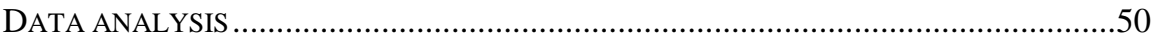

Analyses of similarities (co-occurrence) ….................................................51

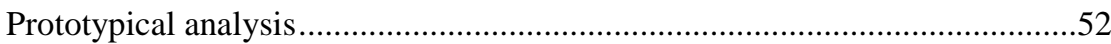

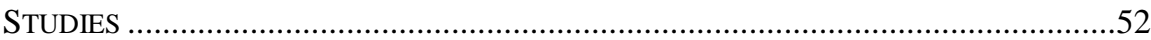

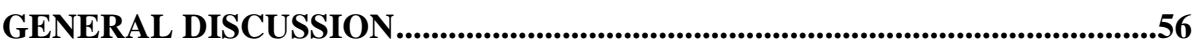

FINDINGS IN RELATIONS TO THE THEORETICAL FRAMEWORK …...........................56

Teachers -the subjects of the investigation of SRs .......................................57

Students with AS and their inclusion - the objects of the SR investigation......63

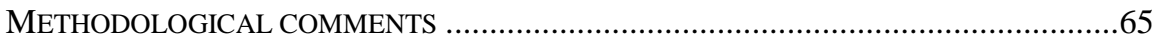

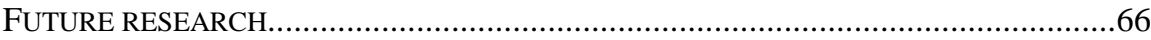

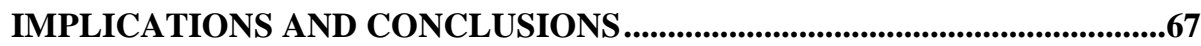

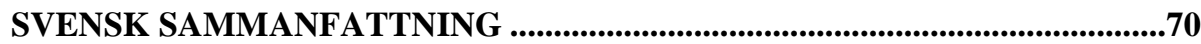

BAKGRUND OCH TEORETISKT RAMVERK …......................................................70

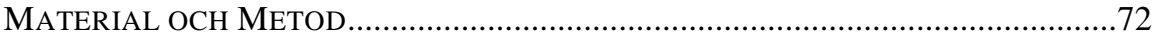

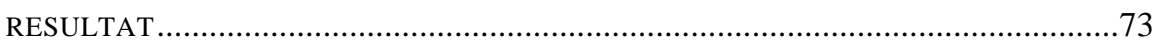




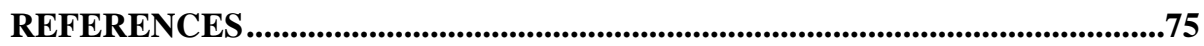

$-6-$ 


\section{Foreword}

A dissertation covering the subject I have chosen must begin by acknowledging the many gifted and dedicated teachers and students out there who made such an inquiry as this possible. I must thank all my colleagues at Lindeskolan that I leaned upon heavily - especially Mona, Gunilla, Ammi and Sofie, you were present at the very conception of this project. Together we tried to deepen our knowledge in the field of special needs education. Also, Astrid, Lisbeth, Erik, Pamela, Bernarda and Per, whatever I have succeeded in creating between these covers would have been a far poorer piece without the sum total of your knowledge and sharing in our day-to-day practice.

I have been guided by three wise men. First and foremost Berth Danermark, your wisdom, experience and theoretical sharpness impress me. Mikael Heimann and Per Germundsson, you gave me support throughout and read my texts with critical eyes. Together you have opened my eyes to the wonders of social research. I also want to thank Pierre Ratinaud for sharing the secrets of IRaMuTeQ and faithfully answering my questions, Mohamed Chaib and Claes Nilholm for expertise at important junctures during the process, Maria HugoLindén for being a wizard at keeping everything organized, Magnus for designing the cover and all my work mates at Örebro University who have been indispensable assets - listening, sharing, laughing not to mention our magnificent finfika, those were important moments I will always treasure

Without the inspiration and support I have received from my family this dissertation would not have materialized. Jennifer, Gabriel, Emily and Julia and families you have supplied me with so much energy by being who you are, always ready to share your experiences of living, learning and belonging.

Last but not least, my fantastic husband Steven who patiently has put up with all the domestic chores, listened without interfering, prepared wonderful meals and making me aware of the importance of staying focused. Without your understanding for what it takes, your love, your sense of humor, and constant interruptions for gardening projects, trips and long runs, I probably would have stayed too focused, taken my job too seriously and forgotten to enjoy the lonely but wonderful journey the writing of a thesis really is! 
My sincere thanks to you all.

Fingerboda, August 2015

Ann-Charlotte Linton 


\section{Introduction}

Because the prevalence of students with an Autism Spectrum Disorder, especially Asperger Syndrome (AS), is increasing, there is also a growing challenge for teachers to provide them with excellent educational opportunities in the mainstream classroom (Emam \& Farrell, 2009; Parsons \& Lewis, 2010). This is a serious problem as many of these students are not achieving basic educational goals despite years of attempts at implementing inclusion programs for students with AS. Evidence that the school environment can become a barrier for students with AS instead of a facilitator for participation implies that the vision of the school as a "melting pot" welcoming everyone is far from being attained (Humphrey, 2008; Westling Allodi, 2007). Several studies have demonstrated that inclusion of pupils with neuropsychiatric disorders in everyday classroom activities is grossly deficient (Ashburner et al., 2010) and sadly less than $50 \%$ of students with AS complete a high school diploma in the US (Newman, 2007). The number of incomplete diplomas in Sweden among students with AS is not specified in national statistics, however numbers are high (SNAE, 2008, 2009).

Although the intentions to establish inclusive learning environments for all students was noble, there are clear signals that exactly the opposite is occurring; namely, the rate of exclusion and drop-outs is on the rise in many countries (Ashburner et al., 2010; School Inspectorate, 2012; SNAE, 2008; 2009). Evidently, there is a large gap between policies to include these students in the mainstream classroom and the actual implementation of these recommendations. A central issue is why there is a lack of appropriate support for students with AS in the classroom that in turn contributes to students' underachieving or dropping out of school (Ashburner et al., 2010).

Teachers play a key role in realizing inclusion since they are responsible for what goes on in the classroom, but we do not fully understand how they view inclusion (Boyle et al., 2013; Grenier, 2010). Consequently, their social representation of including students with AS are likely directly linked to if, and how, these students are incorporated into the mainstream 
classroom. Social representations (SR) are defined as shared images and concepts by which people organize the world around them in order to make sense of it, be it events, phenomena or objects (Moscovici, 2000). An SR is how a given phenomenon, or object, is represented in a population (Doise, 1992; Jodelet, 2008; Moscovici, 2000). These SRs can be seen as products of interactions and exchanges between members of culturally shared groups, such as teachers, in their day-to-day reality (this will be described more fully in the section "What are social representations?"). A central issue is why teachers, despite the distinct policies of inclusion, have not completely achieved this worthy objective? Indeed, it has been suggested that the idea of inclusive education has left its practice behind (Artiles et al., 2006). One question is whether there is a discrepancy in beliefs between policymakers on the one hand who write the directives and the teachers on the other hand who are responsible for implementing them in their daily practice. Moreover, there may be a host of reasons that we do not currently understand which drive teachers' behavior and hinder the inclusion of these students.

Thus, this dissertation aims to contribute to a better understanding of Swedish mainstream teachers' SR of the actual inclusion of students with AS in their classroom. First, to this end, the sample of teachers and their SR of students with AS will be described by employing a novel association task that helps to reduce the political and social bias involved in this topic. Then, the issue of teachers' SR of the actual inclusion of students with AS in their classroom will be investigated. From there, the issue of whether the teachers' SR of inclusion is actually shared by other vital school staff, e.g. principles and the school health professionals will be explored. Finally, the question of whether teachers feel they have the knowledge and experience required to educate the diverse population of students with AS is examined. These issues are all central for understanding inclusion in the modern school and will be related to the theory of social representation in order to understand their meaning and implications. 


\section{Inclusive Education}

This section focuses on key principles and concepts of inclusion which may be defined and applied in different ways (Ainscow et al., 2006; Nilholm \& Göransson, 2014). While inclusion can be seen as a political, legal or an educational idea, this dissertation focuses on inclusion as an educational concept. At first glance this would seem to simply mean offering education in the mainstream classroom to everyone. However, there are several caveats that make this concept multifaceted. For example, even though inclusion is promoted via a democratic political process, it needs to be explored and supplemented at a professional level in education. There has been confusion over the concept and it has often been used interchangeable with integration (Göransson et al., 2011; Nilholm, 2006). Therefore, in this section, the difference between inclusion and integration will be examined and thereafter interpretations of the concept will be discussed. Then inclusion as a political concept will be explored, where it signifies something more desirable than the symbolical notion of exclusion. This includes for example students' rights, access and participation. Lastly, the most common definitions of inclusion will be presented and furthermore the challenges they entail.

\section{Background}

In Sweden as well as in other parts of the western world different integrated forms of schooling were developed in the 1970s and 1980s to reduce segregation as all students were given legal rights to attend the local school (Heimdahl Mattson \& Malmgren Hansen, 2009). When the term integration was used it was seen to be more about placing the individual student in a system which assimilated the individual without adapting the school environment in order to accommodate the student (Jordan, 2008; Vislie, 2003). However, it referred not just to the placement or location of the students but to social and functional aspects of bringing students with and without special educational needs together (Ainscow et al., 2006; Pijl \& Van den Bos, 2001). Hence, integration was more than denoting the physical placement of the student but rather defined as placing students with special education needs in mainstream education settings with some adaptations and resources (Hausstätter, 2014; Vislie, 2003).

The move towards inclusion concerns restructuring ordinary or regular schools to have the capacity to accommodate all children (Nilholm, 2008). In other words, inclusion shifted the focus from students and their needs to 
adaptation of the school environment. Parallel to the development of including all students into regular classrooms the terminology to denote this process changed from integration to inclusion (Vislie, 2003).

\section{Inclusion - numerous interpretations}

It is notable that national and international researchers (e.g., Campbell, 2002; Nilholm, 2006) not only recognized that inclusion lacks clarity but that its complexity leads to confusion. Indeed, the notion of inclusion practices described as "inclusive" differs markedly from one country to another and from context to context while also changing over time (Arthur-Kelly et al., 2013; Hausstätter \& Takala, 2008). In Sweden inclusion is formulated at the national as well as the local level where these goals are to be realized, which means that inclusion needs to be analyzed at both levels since a gap is likely to develop (Göransson, Nilholm, \& Karlsson, 2011). However, this investigation is concerned with the inclusion on the local level.

Furthermore, some models propose a radical interpretation of inclusion whereby it becomes a replacement for special needs education and its associated problems of marginalization and exclusion of all students with disabilities (e.g., Haug, 1998; Thomas \& Loxley, 2007). Others define full inclusion as regular class placement for all students with disabilities, but on a part-time basis for some, while still others put forward the inclusion of students for whom it is appropriate (Takala, Pirttimaa, \& Törmänen, 2009) or even suggest that separate, special schools are part of their inclusion plan (Nilholm \& Göransson, 2014; Spurgeon, 2007). Inclusion interpreted as adapted education and something that teachers need to respond to in their practice simply means that learning has to be planned according to the individual student (Person, 2008; Takala et al., 2009).

Riddell (2009) pointed out that the policy and practice discourse needs to be better articulated since different researchers define inclusion in different ways. As a response to the uncertainty of the concept, and to reduce confusion, Nilholm and Göransson (2014) identified three important characteristics of a fully inclusive school:

- $\quad$ Focus is moved from special education to responding to the diversity within a common school for all students.

- $\quad$ Disability and special needs are viewed as resources.

- $\quad$ Democratic processes take place at all levels of the school.

In addition to the characteristics above, to qualify as an inclusive school, the authors emphasized the need for students' voices to assure that they are 
socially and academically included (Falkmer, 2013; Nilholm \& Göransson, 2014).

Campbell (2002) also recognized that associated with these different aspects of inclusion are some debates about what is implied by inclusion. Ainscow and Sandill (2010) for example suggested that inclusion alludes to communities where differences are celebrated as assets. Yet others have argued that inclusion is a vision with no separate special education but a classroom accessible for all (Thomas \& Loxley, 2007). Hence, researchers cannot reliably study different aspects of inclusion without defining its proposed program.

\section{Students' rights, access and participation}

At the most fundamental level the idea of inclusion is the enhancement of educational access and participation for all. Therefore, inclusion is described as being about participation, not just placement or location. A broad definition of inclusive education was reflected in international declarations and projects. The understanding that education is a basic human right was brought forward in the Universal Declaration of Human Rights in 1948, adopted by the UN General Assembly in 1959, and explicitly specified in the Salamanca statement:

...schools accommodate[ing] all children regardless of their physical, intellectual, social, emotional, linguistic or other conditions (UNESCO, 1994, p. 6).

This view of education as a basic human right has been supported by policies and researchers worldwide (e.g., Ainscow \& Sandhill, 2010; Bentley, 2008; Florian \& Spratt, 2013). The principle based on the Salamanca statement permeates Swedish policy documents and the Swedish Educational Act (2010: 800). All students should as much as possible be taught together which incorporates the values of equity and justice. From this perspective children's rights are emphasized and exchanged for the earlier expression of students' needs (Thomas \& Loxley, 2007). The school expects students with different characteristics to transmit these values to other students. For instance, when people with disabilities are visible and involved in school and other activities in the community it may lead to reduced preconceived ideas (Harma et al., 2013). What we consider as otherness is the result of what historically has been marginalized and considered abnormal, foreign etc. This is in line with Bourdieu's notion of habitus, i.e., in order to understand inclusion and practice inclusive pedagogies there is a need to understand and conceptualize exclusion and what human memory has excluded over the years (see for example Bourdieu, 1984; Durkheim, 1898/1974). Benefits to be gained from inclusion are the understanding of difference and diversity, 
socialization for the individual student identified with special needs, and a reduction in preconceived ideas and behaviors (Bentley, 2008; Jordan Schwartz \& McGhie-Richmond, 2009).

\section{Culturally dependent definitions of inclusion}

The inclusion concept has different meanings in different settings that are shaped by historical, social and civic factors (Ainscow \& Miles, 2008; Armstrong, 2013). These are embedded in beliefs and prescribe norms and routines for daily practice (Graham, 2006). Hence, inclusion is understood according to national conditions and political intention (Florian \& BlackHawkins, 2011; Haug, 2014). For example, major differences in defining inclusion have been identified between the Nordic countries (Hausstätter \& Takala, 2008). These countries are similar yet different. While special education, including segregated provision, is seen as part of inclusion in Finland (Halinen \& Järvinen, 2008; Takala, Pirttimaa, \&Törmänen, 2009), inclusion assumes a reduction of special education in Norway (Nordahl \& Hausstätter, 2009). Still, stakeholders in Sweden promote an in-between position or an integrative inclusive education where the wish for collaboration between special and general education is expressed (Persson, 2008). Hence, culturally dependent meanings have different influences on the issue of inclusion even between the Nordic countries.

However, in Sweden and internationally inclusive education is apparently perceived in different ways. Nilholm and Göransson (2014) distinguished between three qualitatively diverse definitions:

1. The community-oriented definition anchored in the ideal of democratic processes where all students are socially and pedagogically participating and involved.

2. In the individual-oriented definition the main concern is students with difficulties. Degree of inclusion is determined by the situation of the individual student. If the student enjoys school, has good social relationships and reaches the goals, the student, according to the definition, is included.

3. The placement-oriented definition denotes only the physical placement of students with difficulties in the general classroom. Even if researchers are in agreement that this definition is insufficient since inclusion is much more than just physical placement it is still the most common (see Göransson et al., 2011; Slee, 2006).

These main dividing lines of the definitions have a particular order in the sense that an upper level includes a lower level. The community-oriented definition (level 1) includes level 2 and the individual oriented definition includes level 3 (Nilholm \& Göransson, 2014). 
The authors highlighted the problem of inconsistency and the discrepancy in definitions employed by researchers; for example, while some researchers explicitly define inclusion set off from the first or second definition, they use the concept from definition 3 in their analyses (Nilholm \& Göransson, 2014). This makes it confusing and demands a need to explicitly describe how inclusion is understood in the specific project (Göransson et al., 2011).

It has been argued that the placement-oriented definition is a misunderstanding of the inclusion concept (Ainscow et al., 2006; Florian \& Spratt, 2013; Nilholm \& Göransson, 2014). Instead this definition has more in common with the traditional mainstreaming concept introduced in the 1970s and a more integrated system during the 1980s. Nevertheless, it is assumed to be the most commonly held definition among school staff (Göransson et al., 2011; Linqvist \& Nilholm, 2013).

\section{Challenges in defining the concept of inclusion}

If the placement-oriented definition of the inclusion concept is reduced to emphasize the need to include students with disabilities into the classroom, inclusion becomes something that the established school system can distance itself from, in the same way that it can distance itself from the actual pedagogical solutions of inclusion (Grenier, 2010; Hausätter, 2014). Instead the responsibility falls upon the teachers who have to include according to their ability, thus the focus is special pedagogy (Huws \& Jones, 2011; Parsons et al., 2011; Takala et al., 2012). Thereby the goal of inclusion is not necessarily to change the school. To clarify these points, Hausätter (2014) argued that if inclusion is viewed as the ability of the municipality or school to include students with specific needs and measure the extent to which all students participate in the same classroom; inclusion has lost its potential as an alternative to the existing system. The traditional system has not changed but appears in a new disguise of the mainstream (Grenier, 2010; Hausätter, 2014). From this perspective, making the school more available for different groups of students is possible through minor organizational solutions since successful inclusion is measured by the attendance of children with special needs in the mainstream classrooms.

To confront the challenges on the local school level where inclusion is to be implemented, Nilholm (2008) argued for collaboration and cooperation at all levels of the school. Structural barriers need to be discussed such as responsibility for implementation of inclusion and a vision for how to work with students with special educational needs (Lindqvist \& Nilholm, 2013). In order to make inclusive education an alternative to organization of the established school system, it appears that more flexible solutions are needed 
and taken for granted roles within the system need to be problematized.

Otherwise the roles of the professionals are taken for granted in traditional school organizations and more flexible and more appropriate solutions will be overlooked (Nilholm, 2008).

In an analysis of inclusiveness within the Swedish compulsory school system, Göransson et al. (2011) found that there is much leeway in the interpretation of the policies at the local level and that the national policy is not as inclusive as often believed, an important background in this investigation. As yet, based on their analysis, students' needs are still viewed as shortcomings, the learning goals are contradictory to the celebration of diversity; that is, everyone despite differences, should achieve the same educational goals stipulated by the system (Göransson, 2006). Last and foremost, it has been underscored that understanding the challenges within the inclusive education should extend beyond policy, practice and disability to question why we adopt or fail to adopt inclusion (McIntyre, 1990). 


\section{Asperger Syndrome - part of Autism Spectrum Disorder}

In this section, necessary background on how AS is defined and what kinds of factors are thought to influence these students in the classroom such as environmental aspects, pedagogical aspects and educational support will be provided. Also the realm of the problem for the student as it relates to school absenteeism will be considered and finally the responsibility that teachers may have for fulfilling the goal of inclusion will be delineated.

Autism is a spectrum disorder with a wide span of diverse strengths and needs within this cohort. As a pervasive developmental disorder the degree or severity might change over development. AS is a separate neuropsychiatric disorder in DSM-IV (APA, 1994) that involves impaired ability in social interaction and communication and restricted repetitive behaviors, interests, and activities. In DSM 5, introduced in 2013, AS is part of the broader autism spectrum syndrome (ASD) which incorporates the former DSM-IV diagnostic categories autistic disorder (autism), Asperger's disorder, childhood disintegrative disorder, and pervasive developmental disorder not otherwise specified (APA, 2013). ASD is distinguished by: 1) deficits in social communication and social interaction and 2) restricted repetitive behaviors, interests, and activities. Both these components are necessary for the diagnosis of ASD (APA, 2013). A greater proportion of males compared to females (approximating 4:1) has been a consistent finding in ASD (BaronCohen et al., 2009).

The prevalence of AS also varies between countries and studies. In a Swedish study of children with AS the prevalence was suggested to be 0.30.4 percent (Ehlers \& Gillberg, 1993). In a later study prevalence of AS was estimated to be 7 -11per 10,000 in Sweden (Gillberg et al., 2006). However, more recent studies do not separate sub-entities in ASD. An investigation in the UK found that ASD occurred in up to $1 \%$ of the population (Simonoff et al., 2008) which is concurrent with recent prevalence studies in children the US (Kogan et al., 2009). In a more recent study the prevalence in young school children in the UK was found to be $1.6 \%$ but sub-entities were not specified (Baron-Cohen et al., 2009). Consequently, there is uncertainty concerning the prevalence of AS and we do not know if it is actually increasing.

Although the new DSM 5 does not highlight the sub-entities, AS is still used as a term by educators in Sweden, many people have already received the diagnosis and it is still included in ICD-10 (Tsai \& Ghaziuddin, 2014). 
The term Asperger Syndrome, sometimes also described as high functioning autism, is generally thought to be at the mild end of ASD, and more prevalent than "classic" autism. To fulfill the criteria of AS, according to DSM-IV-R, intelligence needs to be normal or above, and speech must have developed according to set standards.

In addition to the diagnosis-based behaviors mentioned above, other symptoms are common in AS. For example, persons with AS often have impaired abilities in executive functions, such as flexibility, planning, organization, goal setting, and use of working memory (Pennigton \& Ozonoff, 1996). Furthermore, difficulty in social interactions in AS have been linked to impaired executive functions. The ability to attribute mental states to others ('theory of mind') is reduced in these individuals (Happé, 1993). They have a detail-focused processing of information and weak central coherence, which means that information is processed in a piecemeal way at the expense of contextual meaning (Frith \& Happé, 1994). They may also have sensory difficulties: over-sensitivity or under-sensitivity for certain sounds, touches, odors etc.; periods of hyperactivity; sleeping and eating disorders, etc. (Adamson, O’Hare, \& Graham, 2006; Attwood, 2007). However, while these symptoms are relevant, none of them are required for the diagnosis.

In the gathering of data for the following empirical research, the term AS diagnosis was used. This is a term that individuals with the diagnosis tend to prefer (Larsson Abbad, 2007) and also the focus of our inquiry within the broader ASD. Henceforth, only the abbreviation AS will be used since the focus of this thesis is this sub entity only.

\section{Environmental aspects}

If the main idea behind the Salamanca statement is to increase social learning, the environment needs to be adapted appropriately. In fact, the school environment can be a major challenge for students with AS because they are vulnerable to stress and unpredictable situations (Attwood, 2007), which in turn can lead to school absenteeism and early school leaving (School Inspectorate, 2012; Starr \& Foy, 2012). How the disorder impacts the individual largely relates to the environment and its demands (Jordan, 2005; Parsons et al., 2011; Ravet, 2011).

Since a large number of individuals with AS experience difficulties in sensory processing (Adamson et al., 2006; Attwood, 2007) researchers have expressed concern considering the bustling classroom. The overload of stimuli experienced by these students and their inability to filter background noise and hypersensitivity to certain sounds can lead to catastrophic responses (Ashburner et al., 2008; McLaren, 2013). Given the idiosyncratic 
difficulties in sensory processing and the social and emotional understanding, providing a suitable school environment can be a challenging task (Ashburner et al., 2010; Baker et al., 2008; Frederickson et al., 2010).

\section{Pedagogical aspects}

Facilitating life in the general classroom for students with AS is closely linked to the way teachers and other educators understand and provide for these students (Humphrey \& Lewis, 2008; Jordan, 2005; Parsons et al., 2011). Many of the methods used in pedagogical practices in Sweden and the modern western world are based on the perception of children in general, not on children with atypical development such as children with diagnoses such as AS (Hejlskov Elvén, 2009; Jordan, 2008). For instance, Piaget (1964) talked about the child as actively trying to make sense out of the world and trying to find meaning in daily activities, developing central coherence. Students with AS do not necessarily make sense out of activities in the way other students do; in fact, they often have problems with central coherence (Attwood, 2007; Humphery \& Lewis, 2008). Frith and Happé (1992) proposed that persons with AS have a different cognitive style which involves a tendency to demonstrate a detail-focused processing and an inability to extract "the big picture" which has consequences for open-ended tasks. Despite the condition potentially changing over time and their comparatively high academic and verbal capabilities, these students retain most of the AS-related impairment (Esbensen et al., 2009; Larsson Abbad, 2007). However, recent research suggests that a few individuals with an AS might lose the diagnosis with age (Fein et al., 2013).

Students with AS have been described as having fewer friends and being more involved in nonsocial activities than their typically developing peers which may be explained by their restricted executive functions such as response inhibition and cognitive flexibility (Attwood, 2008; Jordan, 2005; Pisula \& Lukowska, 2011). They show strains in emotional comprehending which refers to the ability to detect the facial expressions as well as the presumed emotions of others in diverse social situations (Attwood, 2007; Baron-Cohen et al., 2009; Falkmer, 2013). Such efforts are assumed to curb their opportunities for participation in school activities and affect relationships with their teachers and peers (Falkmer, 2013). Since students with this disorder have difficulty reading and interpreting social cues, which may be obvious to others (Humphery \& Lewis, 2008), they miss out on opportunities for learning and development that other students receive. For example, compared with their peers, students with AS are less likely to respond to questions orally, give presentations in front of the class, or collaborate with peers (Falkmer, 2013; Newman, 2007). 
The demands on the students' ability to interpret a task increases with grade level so they need to plan their studies. In general this ability gets better for children with age. However, this is not necessarily true for students with AS (Baren-Cohen et al., 2009). In fact, to make sense of tasks which involve different levels of abstract interpretation may be a challenge that persists. Typically, it does not get easier with time to interpret unspoken insinuations and tacit assumptions (Pisula \& Lukowska, 2011). This could be one explanation for stress increasing with grade level as tasks become more abstract on higher levels (Humphery \& Lewis, 2008; Myles, 2003).

\section{Educational support}

Limited research in Sweden has indicated that while teachers find the experience of inclusion beneficial for the student with AS there is a need for considerably more educational and social support and flexible solutions (Berhanu, 2011; School Inspectorate, 2012). It can be said that in spite of good intentions for an inclusive school environment, the lack of support or inappropriate support causes suffering and fewer students with AS complete a high school diploma (SNAE, 2009). Concerns about the various challenges in the implementation of inclusive education due to lack of support and resources have been expressed. For example, Emam and Farell (2009) explored how teachers shaped their views of support arrangements for these students in English primary and secondary school and found that school staff felt they needed teaching assistants in order to manage the unique problems that the inclusion of pupils with AS can present.

\section{The problem of exclusion: Absenteeism}

An increasing number of reports have shown that school dropouts and absence without valid reasons for an extended period is a growing problem among students with AS in Sweden and other western countries (Almvik, 2010; Parsons \& Lewis, 2010; SNAE, 2009; School Inspectorate, 2012). Long-term school absenteeism can lead to serious and significant adverse impacts on the child's emotional and social development and adaptation to society (Konstenius \& Schillaci, 2010). It is not uncommon that school absenteeism is developed over a longer period of time without being addressed or dealt with effectively (SNAE, 2008).

In many cases, an absent student is not a problem in the direct teaching situation but if students do not feel involved in or part of school activities there is a major risk that students are marginalized (Akin \& Neuman, 2013; Jordan, 2008). Staying at home could be a way to deal with stress and burnout (Almvik, 2010; Pyle \& Wexler, 2012). In addition to the individual's suffering, the problem usually involves a great strain and challenge for 
parents and school (Starr \& Foy, 2012). Even if the student returns to school there might be emotional outbursts at home and depression (Hejlskov Elven, 2009; Humphrey \& Lewis, 2008). It also requires extensive resources and collaboration between different professions in schools (Chiang et al., 2012), mental health and social services.

Ultimately, these young people can come to stand outside the labor market, in Sweden as well as other parts of the world, which today clearly states the need for completion of a high school diploma to compete for jobs (Arnesen \& Lundahl, 2006; Lake et al., 2014;Wehman et al., 2014). Moreover, unemployment for a long time can lead to chronic stress conditions and passiveness (Hetzler, Medin, \& Bjerstedt, 2005). This in turn increases the risk of developing poor self-image and lowered self-confidence that makes it even more difficult for these individuals to assert themselves in social contexts and in the labor market (Wehman et al., 2014). To promote development and work to preventively stop students with AS from being absent from school, requires collaboration on the goals of inclusion to generate a climate that supports these students and their development and participation (Batten, 2005).

\section{Inclusion of students with AS}

In this section the challenges of inclusion among students with AS and what contributes to students underachieving or dropping out of school will be discussed. The large gap between policies to include these students in the mainstream classroom and the actual implementation of these recommendations will be explored. A central issue is why teachers are falling short of including students with AS, and the role of education for teachers about the specific disability. In addition, the criticism of including all students with AS, will be discussed.

Despite national and international guidelines and declarations which emphasize the importance of education in the general classroom, the reverse situation is reflected in schools in Sweden concerning students diagnosed with AS (SNAE, 2009). Studies have shown that these students have an increased risk of low participation in school which might lead to exclusion (Ashburner et al., 2010). The limitations of a specific group to participate in general education, even if it is unintentional, ultimately leads to discrimination in civic and social life. For example it could lead to potential barriers to employment and social exclusion (Thomas \& Loxley, 2007; Westling Allodi, 2007). 


\section{Teachers and inclusion of students with AS}

Evidence has shown that many teachers feel ill-equipped to support students with AS in the general classroom (Symes \& Humphrey, 2010). Disparities in training can leave teachers feeling disheartened while students with AS may miss opportunities to reach their full potential (Allen \& Cowdery, 2005; Osborne \& Reed, 2011; Warnock, 2005). Indeed, international research has shown that results for students with AS, in inclusive schools, are among the poorest of any disability category (Emam \& Farrell, 2009; Shattuck et al., 2012). Here, teachers believe their training does not equip them with skills and knowledge necessary to teach students with AS (Hein et al., 2011; Robertson et al., 2003; Starr \& Foy, 2012; Syriopoulo-Delli, et al., 2012). For example, a British study found that only $5 \%$ of teachers received training about disability even though many teachers had a child with AS in their class (McGregor \& Campbell, 2001).

In the Swedish context there has been a reluctance to register disabilities among students since it disagrees with the philosophy of inclusion (Nilholm, 2007). However, studies conducted by the School Inspectorate (2012) and SNAE (2009) provided evidence that many of these students struggle to cope with education in the general classroom. Also, the Swedish Association for Autism and Asperger Syndrome (2007) found that only 43\% of students with AS had attained all the goals set for compulsory school. There is consequently an urgent need to explore the challenges experienced by teachers to contribute to enhanced support and improved quality of life for this population (Chiang, Cheung, Hickson, Ziang, \& Tsai, 2012; Gerhardt \& Lainer, 2011).

\section{Criticism of inclusion for students with AS}

One of the criticisms of inclusion for everyone with AS is that this is a very heterogeneous group (MacLaren, 2013). Also it is argued that the medical category emphasizes difference and students with AS may become associated with specific identities (Graham, 2006). Hence, assumptions about diagnosis shape interactions with students and influence outcomes such as expectations. Low expectations lead to lower self-esteem and exclusionary practice (Grenier, 2010) and contradict a community based or a student-orientsed definition of inclusion (Haustätter, 2014; Nilholm \& Göransson, 2014). Thus a cycle of impaired performance might evolve and further lower expectations of both teacher and student (Gilmore, Campbell, \& Cuskelly, 2003).

At the same time a diagnosis may be inclusionary as it makes it possible to identify and meet individual needs. Relevant adaptations to the school environment can only happen if "difference" is recognized (Graham, 2006; 
Lindsay et al., 2013; Ravet, 2011). In order to treat all students the same there is a need to treat them differently (Jordan, 2008). However, expectations may still be high despite the diagnosis; such an approach could be viewed as a student-oriented definition of inclusion. This bipolar or dilemma approach has been recognized by researchers (Dyson, 2001; Norwich, 2008).

\section{Research on inclusion of students with AS}

In Sweden there is an apparent lack of research in educational provision specifically targeting students with AS (SNAE, 2009). However, two doctoral theses, one exploring students in a special resource program for students with AS (Hellberg, 2007) and the other studying participation in mainstream school of persons with ASD (Falkmer, 2013), stressed the importance of teachers' knowledge and structured educational provision for these learners. Reports showed that national projects specifically targeting individuals within the autism spectrum received (consumed) only $1 \%$ of all funded disability research. None of these projects examined the educational provision for learners with AS (Rönnberg, Classon, Danermark, \& Karlsson, 2012). This limited body of research, in combination with the great variability within the cohort, makes it extremely difficult to draw general conclusions about successful educational provisions for students with AS in Sweden. 


\section{The role of teachers}

Research has shown that teacher and student interaction is one of the most important factors for supporting students to complete their education (Hattie, 2012; Whannell \& Allen, 2011). Also, the teachers' behavior is very important because it is a model for relationships in the class (Breeman et al., 2015; Silver, Armstrong, \& Essex, 2005). A democratic climate in the school and class promotes democratic values in students and contributes to the development of attitudes of responsibility and participation, not only at school, but also in the larger community (Hein et al., 2011).

The activities in school settings are typically based on interaction and communication between teachers such as problem solving and peer communication, which in turn are grounded in teachers' social representations (SR). However, complex organizations like schools are multilayered and teachers' frame of mind vary in different contexts. Particular groups of teachers will hold SRs which are informed and anchored in a specific culture and tradition; for example that ability is more valued than effort in achievement gains (Hattie, 2012). These SRs are remnants of earlier political and educational reforms influencing the teacher training programs.

Research has shown that teachers unmistakably play a vital role in the implementation of reforms and within the contemporary policy reforms for inclusion emphasis is placed on teachers to be sensitive to the variety of learning needs (see for example Ainscow \& Sandhill, 2010; Hattie, 2012). The decentralization of Swedish education from the state to the municipality was supposed to adapt more to local conditions but not necessarily adapt to each student (Göranssson et al., 2011; Westling Allodi, 2007). Instead, this was viewed as classroom chores where teachers needed to be committed to inclusive pedagogy and take responsibility (Jordan et al., 2009). The concept "inclusive pedagogy" was defined by Alexander (2004) as "the knowledge and the skills required by teachers to inform the decisions they make about their practice" (p.11). This is in line with Rouse (2009) who stated that "knowing," "doing" and "believing" are prerequisites for successful inclusive pedagogy. Therefore, beyond knowledge of teaching and learning, values and norms dominate teachers' SR of their own role as educators in their day-today reality.

Earlier research conceptualizing individual beliefs and attitudes is of relevance in this research. Abundant research on teachers' attitudes and beliefs, and how these beliefs might have developed, have pointed to the 
importance of teachers' positive attitudes and beliefs in themselves as change agents (Hattie, 2012). Indeed, the beliefs and attitudes of teachers and other school staff are in different studies found to be key components in creating an inclusive environment for all children (Avramidis \& Norwich, 2002; Emam \& Farrell, 2009; Frederickson et al., 2010; Jerlinder et al., 2010).

Hattie (2012) argued that educators are employed to be change agents. In other words, for change to come about in the school arena, teachers need to believe in the suggested changes in learning intentions as many studies have shown that students achieve in the way the teachers expect them to achieve. Instead of simplifying material and lowering expectations the challenges may be needed for the students to exceed in school (Jordan, 2008). Hattie wrote:

It is about teachers believing that achievements is changeable, enhanceable and is never immutable or fixed, that the role of a teacher is as an enabler not as a barrier, that learning is about challenge and not about breaking down material into easier chunks, and it is about teachers seeing the value of both themselves and students understanding learning intentions and success criteria. (p. 162).

Therefore, probably one of the most momentous facts is that teachers' beliefs and attitudes impact expectations which in turn mold students' selfexpectations, i.e. Pygmalion effect (Weinstein et al., 1987). There are researchers who express the importance of examining the beliefs and attitudes towards students with AS among teachers in order to further develop the current political reforms of inclusion placing increasing emphasis on adapting provision (Avramidis \& Norwich, 2002; Emam \& Farrell, 2009; Florian \& Spratt, 2013). And, as mentioned above, when a student has positive expectations it will in itself lead to increased success (Woodcock \& Vialle, 2011).

Teachers are held responsible for supporting and adapting their lessons and learning environment for all students therefore the frame of mind of teachers plays a vital role (Jordan, 2008). There seems to be a gender difference in the enthusiasm to include students with AS. For example, Demetriou, Wilson, and Winterbottom (2009) found that female teachers had a tendency to more frequently send male students off to special units instead of providing for them in the general classroom. The high frequency of boys diagnosed with AS, and the discrepancy in male and female teachers' approaches is likely to have an impact on provision (Abikoff, Jensen, \& Arnold, 2002; Coles et al., 2012). Due to the fact that impairments in social skills become more prominent at higher levels, differences between teachers' perceptions in kindergarten and secondary school have been noted (Batten, 2005; Humphrey \& Lewis, 2008; Myles, 2003).

Hence, understanding teachers' beliefs and attitudes are likely to lead to beneficial knowledge to enhanced inclusion at a time when the issue of exclusion could be reduced (Hein et al., 2011; Sharma et al., 2008). Indeed, 
drop out is a sign of school failure to provide the learner with appropriate opportunities.

Hattie (2012) suggested that many teachers focus too much on ability and that one aspect of how well students perform is related to expectations held by teachers and how their expectations differ and lead to "self-fulfilling prophecy" through which teachers' low expectations reduce students' academic performance and lead teachers to give less challenging coursework. Therefore, teachers' beliefs concerning the needs of students with AS are one important aspect in helping them achieve their full potential in the mainstream classroom since differences in achievements can be viewed as partly related to whether teachers believe that ability is changeable and more related to effort (Avramidis \& Norwich, 2002; Emam \& Farrell, 2009; Lindsay, 2013).

A successful educational provision for students with disabilities can partly be seen as depending on the experiences of the teacher (Avramidis \& Norwich, 2002; Emam \& Farrell, 2009). Given the situation today, most teachers rely on their own previous experiences in order to cope with the challenges students with special needs present (Hattie, 2012; Mavropoulou \& Avramidis, 2012; Sharma, Forlin, \& Loreman, 2008). David and Kuyini (2012) found that changes in teachers' attitudes have occurred during the last decade partly due to teachers experiencing working with special needs. This is congruent with Takala and Astrid (2014) who noted similar trends among Swedish and Finnish teachers.

\section{The organizational level}

Teachers today may be in favor of inclusive pedagogy but lack support in implementing an inclusive practice because of organizational barriers (Shevlin et al., 2013). Evident in studies is the link needed between teachers' individual practice and broader institutional forces for an inclusive environment (Berhanu, 2011; Robertson \& Chamberlain, 2003). Studies on teachers' beliefs and attitudes towards inclusion have reported lack of support and development of inclusive environment from the leadership (Kugelmass \& Ainscow, 2004). Inclusion strategies are found to be most efficient when school leaders, school health professionals (SHPs) and teachers widely share a common vision and when there are coordinated efforts to work in ways which are consistent with it (Berhanu, 2011; Lindqvist \& Nilholm, 2013). Therefore, in order to maximize inclusion, attention needs to be placed on several levels simultaneously: the organization level, the classroom level and the individual student level (Boyle, Topping, \& Jindal-Snape, 2013). Even if 
it is unlikely to fully close the gaps, there is a need to move toward a shared belief of inclusion so that the gap between policy and practice can be maximally reduced.

In Sweden, research has shown that the school administration is pivotal in preventing segregation (Berhanu, 2011; Heimdahl-Mattson \& MalmgrenHansen, 2009). For example, it is the principal's duty to establish an individual educational plan for students with special educational needs (Isaksson, Lindqvist, \& Bergström, 2007; Lindqvist \& Nilholm, 2013) and organize support for students with special needs (Heimdahl Mattson \& Malmgren Hansen, 2009; Lindqvist et al., 2011). Also, the issue of need for guidance and development of skills and continuing education decisions are made by heads.

In their quest to include, teachers may need the support from SHPs and also tools to appropriately provide. For example, educators can proactively collaborate with specialists such as special education needs coordinators (SENCOs) and adapt the curricula according to the individual student (Cowne, 2005; Lindqvist, 2013). Hence, the structural level plays a significant role in preventing segregating mechanisms (Berhanu, 2011; Boyle et al., 2013).

\section{Different paradigms}

Another way of understanding the gap between the policy and practice may be the scenario that teachers' beliefs are in fact anchored in a different paradigm. Considering that the Swedish teacher training program of 2001 articulated a vision of inclusion (SOU, 1999, p. 639), many teachers had their training in an earlier paradigm of segregated provision for students with special needs. Therefore, teachers having their training in different paradigms would impact and shape their SR of inclusion of students with AS differently. An assumption is that teachers having received the more recent education would have a different notion of allocating resources to provide inclusion and would have a more positive view of inclusive pedagogy. However, as mentioned above, teachers alone cannot realize inclusion without a shared common vision with other school staff (Nilholm, 2008).

Before delving into teachers' and other school staff's knowledge and beliefs, let us consider how knowledge is acquired from a social viewpointan important perspective in this dissertation. 


\section{Knowledge as a social product}

Crucial background to consider is how teachers' gain knowledge about reforms such as the inclusion of all students. While we often think of course work, much of knowledge is also the product of social processes between teachers as well as between a teacher and other school staff and others in society. This knowledge is communicated by language where media also play an important role in the production and communication of knowledge. In fact, there is a developed theory that considers knowledge as a social product.

In their book The Social Construction of Reality: A Treatise in the Sociology of Knowledge Berger and Luckman (1966) claimed that knowledge is a product of human interaction developed in social processes. What is valid or not is based on people's experiences and common understanding and negotiations about what is real in their social world. Hence, the taken for granted knowledge is a product of a certain time and place. People's observations are re-presentations of the world seen through a screen colored by culture, history and ideology (Abric, 2001; Sousa, 2011). These social representations (SR) of categories and concepts can be seen as products of people, interaction and exchanges between members of culturally shared groups. Given that knowledge is viewed as a social product it is closely tied to its local and cultural context and a specific time point in the development of that culture (Farr, 1993). When we learn things about the world, cultural traditions, emotions and daily practices etc. serve as filters through which the knowledge is diffused. This common sense knowledge is our SR and remnants of our culture and invisible to us in our practice. This in turn could create problems for teachers when implementing new reforms and polices such as inclusive education. For example, teachers, who are in favor of inclusive education, may unconsciously employ the compensatory pedagogical approach instead of abilities and the unique profile of the student. These competing SRs can be seen as a struggle between the idea of special education and an inclusive school for all comers. Moscovici (2000) described this conflict as consisting of both consensus and contradictory symbolic codes.

This dissertation is concerned with teachers' and other school staff's SRs, and how they impact on inclusion. 


\section{Teachers' SRs - where do they originate?}

Let us look at the development of special needs within the educational system. Special education came about for students with a lack of abilities; hence, they had special needs. Consequently, one can see a clear distinction between those who were able and those who were unable to attend regular education (Persson, 2003). Indeed, this separation promoted a view of students as being mentally or physically different. The message is clear: the focus is on students' needs instead of a wider understanding of segregation in the school context and its implication for segregated lives.

\section{Special needs and the medical model}

The perception of individual deficit has its roots in the medical view of disability which has been the dominant model in teacher training and educational provision for years (Thomas \& Loxley, 2007). Therefore teachers are unaware of the malfunction of the general school system to provide a school for all, and a failure to recognize the social and cultural forces behind such beliefs. The medical model is good in its place but it does not seem very helpful in consideration of students who are experiencing failure in school and their relationship to the school setting. Instead, there is a need for understanding the interplay between the individual, environment and the educational provision that may well be multifaceted. If focus is primarily on the individual and a deficit model, it can lead educators to accept conceptualization of medical categories that are often used as an argument for determining who fits into mainstream schools (Isaksson et al., 2007; Lindqvist \& Nilholm, 2013). It may allow the school process to go on leaving the ideological discussions of inclusion out (Haustätter, 2014; Takala et al., 2009).

\section{The psycho-medical paradigm}

Diagnoses in schools gained ground in the 1990s and have been used for organizing and providing resources, but it is a hotly debated topic (Isaksson et al., 2007). This is due to two interrelated factors: the growing political and ideological force for inclusion in the general classroom and the growing awareness of categorization of students is not always beneficial for the individual (Connor, 1999; Haug, 1998; Hjörne \& Säljö, 2008; Humphery, 2008). This argument originated in the idea that special education needs is a social construction: the school acts as a social institution in establishing the 
construct (Cremin \& Thomas, 2005). In contrast, the medical model argues that the school plays a minor part: the difficulty exists independently of how we talk about the difficulty (see above).

The dilemma involved concerning diagnosis of students which make inclusion complex has been brought forward by researchers in Sweden (see for example, Berhanu, 2011; Nilholm et al., 2013). On the one hand, mainstream teachers need the medical diagnoses in order to make sense of the problems the students might encounter in the general classroom in order to prevent misunderstandings. Otherwise misjudgments by teachers or limitations in identifying anxiety and depression can lead to school refusal (Armstrong \& Hallett, 2012; Florian, 2007). Thus, the diagnosis can be seen as an introduction to obstacles students might experience before it is too late (Batten, 2005). On the other hand, diagnosis can lead to stigma and exclusion.

To conclude, teachers' provision for students with AS and their individual and collective sense of responsibility for student performance is embedded in the school context within which teachers' SRs are rooted. Therefore, to gain a sense of teachers' SRs in the general classroom, we need to proceed to explore how we can capture the SRs that teachers hold. Also, there is a need to explore the SRs at the organizational level since previous research points to the importance of their involvement in the implementation process of inclusion (Berhanu, 2011; Boyle et al., 2013; Farrell et al., 2007; Nilholm, 2007; Heimdahl Mattson \& Malmgren Hansen, 2009; Jordan et al., 2009). As mentioned earlier, teachers' and other school staff's SRs are understood as guiding their inclusion of students with AS, namely, students' ability or lack of it. 


\section{Social representation theory: How it relates to inclusion}

The concepts and models developed within the social representation theory (SRT) comprise the theoretical points of departure (Moscovici, 2000) in studying the SR of inclusion of students with AS as a social phenomenon in a school setting. An analytical perspective on the individual level rather than social level exploring teachers' beliefs and attitudes could be that of schemata or scripts used in cognitive science. However, schemata are appropriate at an individual level while SRs are more relevant for a group and macro level. Since the idea behind this research is to explore the beliefs of teachers as a professional group (Ratinaud \& Lac, 2011) and not as individuals the SRT is more applicable. Also, schemata are context specific and used in terms of individual learning and memory whereas SRs are by definition widely shared and distributed thus more familiar to the general population.

Earlier research into inclusive education has examined teacher beliefs and behaviors in isolation: in order to make sense, they may be looked at in context, together (Smith \& Green, 2004). From an SRT perspective, beliefs and behavior coexist as part of the system of meaning (Moscovici, 2000). They are simultaneous. Therefore, the theory can help make a step forward in elucidating teachers' SRs of students with AS and their inclusion and bridge the gap between what teachers say they do and what they actually do in the school context. Hence, the theory can be used to help explore whether the policy of inclusion has gained vital support from teachers in order to succeed.

Drawing on SRT, the point of departure is that knowledge is symbolic and social meaning making is created through a system of negotiations in an on-going process. Since SRs are constructed together with other people they are part of a social context which is embedded in a wider cultural system. SRs have been studied in the field of education in earlier research, for example, teacher training (Chaib \& Chaib, 2011), teacher's work (Sousa, 2011), school exclusion (Howarth, 2004), students' SRs of disability (Harma et al., 2013), students' SRs of higher education (Andersén, 2011), preschool as a pedagogical practice (Granbom, 2011), career and guidance (Bergmo Prvulovic, 2015) and in many other fields such as health care, foods and technology. 


\section{The origin of SRT}

SRT was born in France after the influential work of Moscovici (Moscovici, 2000). The theory has its roots in Durkheim's idea of collective representations (Durkheim, 1898/1994). These collective representations can be seen as a defined framework for a community. They are closed systems since there is one principal knowledge source (e.g., religion) and handed down by traditions and institutions and resistant to social change (Jovchelovitch, 2007). Today, in the western world, there is an excess of knowledge sources due to globalization, multiculturalism and the internet among other things.

The SRT is a theory of "social knowledge" which briefly deals with how different groups together form a collective notion of the reality that surrounds them. A group can be defined in many different ways however in this thesis a group is defined as a:

social unit which consists of a number of individuals who stand in (more or less) definite status and role relationships to one another and which possesses a set of values or norms of its own regulating the behavior of individual members, at least in matters of consequence to the group (Sherif \& Sherif, 1956, p. 144).

Thus a social group is considered a collection of interacting individuals who participate in similar activities and whereby some reciprocity and mutual awareness exists among individuals. Central to the SRT is the link between the individual and society. All groups are embedded in a social and environmental context, where knowledge formation of individuals comes about through social interaction. Different kinds of knowledge such as myth, religion, ideology, science, common sense or a mixture of these have their own logic for understanding the world around them. Consequently, knowledge is an activity tied to the context where it appears and the group is considered to be the basis for how the world is perceived, understood and interpreted. Together, people develop this common reality and everyday knowledge (common sense) that holds them together and helps them to communicate and orient themselves in their social life (Chaib \& Orfali, 1996). The communication between members of a community helps produce a variety of representations. They may persist over a longer period of time and influence new ideas:

Our past experience and ideas are not dead experiences or dead ideas, but continue to be active, to change and to infiltrate our present experiences and ideas

(Moscovici, 1984, p.16).

By means of a model for understanding the metasystem that adds order to our sense of reality, SRT elucidates how groups and communities share representations to jointly construct a common reality. Within SRT there are 
parallel existing representations which can be both contradictory and complimentary, in the community and for the individual, called polyphasia (Jovchelovitch, 2007; Moscovici, 2000). For instance, we move between professional contexts where a certain phenomenon has a specific purpose whereas in our social life we are part of a different social context where the phenomenon is of a different character. Thus, we think and communicate about the phenomenon in different ways. This means that the meaning is closely tied to the social context.

\section{What are SRs?}

SRs are complicated since they involve both process and content. While SRs in general are said to be shared common sense views we hold as a process, they are a sequence of psychological operations including exploration, recognition, categorization and sense-making concerning a given phenomenon or object (Lahlou \& Abric, 2011). This process is based on previous experience. As content it is the result of that process in the form of some re-presentation of the "object" by the subject.

As mentioned earlier, representations were originally used by Durkheim, and expanded upon by Moscovici (2000). He defined them as "systems" of preconceptions, images and values, which have their own cultural meaning and persist independently of individual experience (Moscovici, 2000). The "systems" of meaning serve as tacit or implied constructions that guide and inform verbal and nonverbal communications. In this way, humans construct frameworks of shared references through interaction with each other (Wagner et al., 1999). These shared views can be looked upon as SRs. They are distinguished from representations that are unique only to a few individuals. Hence, our understanding of the world is socially shared with members of a social group and the needs of that particular group.

We are born into society and culture, we are also born into common sense knowledge, it is all around us and we adopt it for better or worse (Marková, 2003, p.139).

Since SRs can be seen as the mechanisms people use to try to understand and make sense of the world around them, they are constantly re-presented and developed within the framework of a specific community and culture.

From this perspective, beliefs and behavior coexist as part of the system of meaning. Thus one does not cause the other but SRs can be used to understand an issue. SRs are not mirrors of the world nor are they the world itself, but they exist in the world (Jovchelovitch, 2007) and rest on the triad self-object-other(s) which is re-presented and communicated in dialogues (Fig 1). The "object" can also be an event or a phenomenon. 


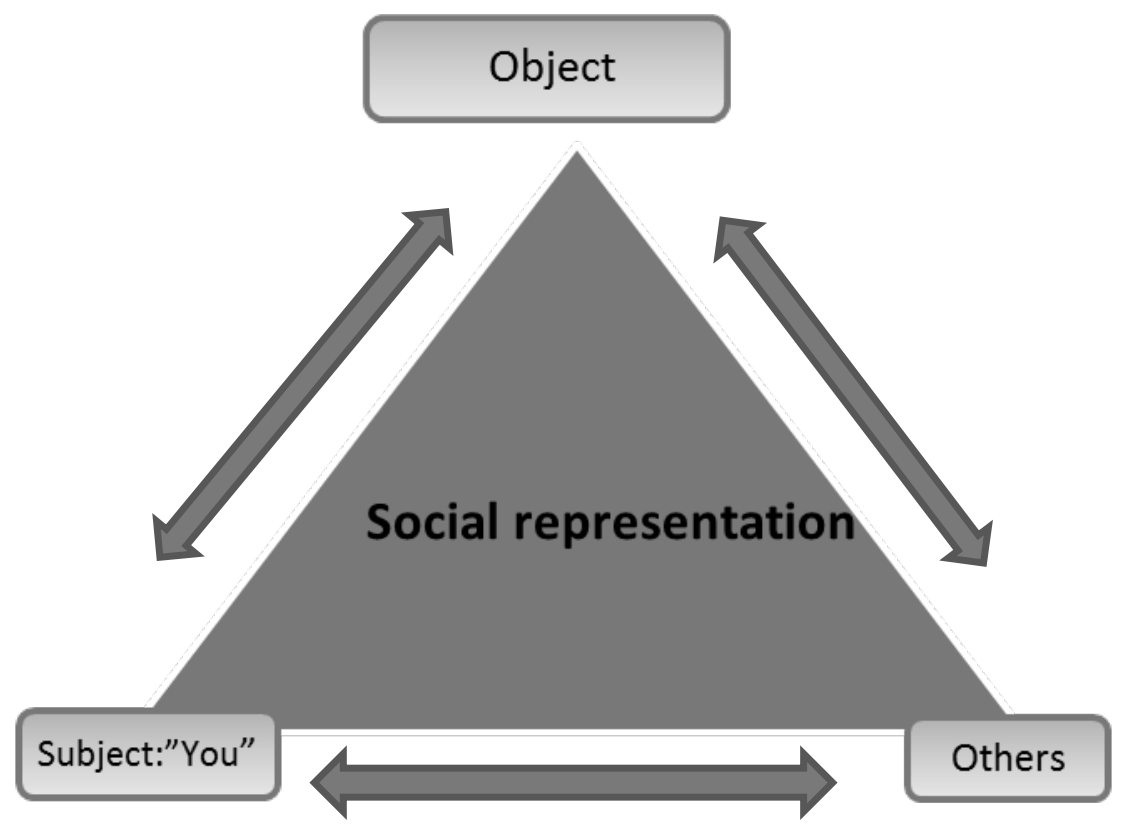

Figure 1. A social representation exists between you, others and the object (Jovchelovitch, 2007)

Whenever a new phenomenon appears there is a need for labeling and to enable communication about this "object." Jovchelovitch stressed the role of SRs in interaction between others and the object:

Representation emerges as a mediating structure between subject - other - object. It is constituted as labour, that is to say, representation structures itself through the labour of communication and action that links subjects to other subjects and to the object world. In this sense it is perfectly plausible to say that representations are communicative action (2007, p. 34).

These interrelationships are not always the same. In the construction of SRs, Jovchelovitch (2007) emphasized different aspects such as authority and emotional ties between the participating partners to be considered. Also, since we move between different groups with different conditions and needs, one and the same phenomenon can have different relevance and different demands on shared understanding. Thus, the production of representations depends on the social, emotional and the communication act between the actors. 
It is through two processes that new information or experiences are made sense of, namely anchoring and objectification, grounding the unfamiliar in the familiar (Moscovici 2000). The "new" becomes part of the structure of the representational fields involved. The resulting preferences and biases which they cause reveal strong correspondences with the social and psychological context they grow out of. Therefore, the social context and representations mutually constitute each another (Jovchelovitch, 2007). However, Moscovici did not clearly specify the cognitive sequences that lead to representations.

\section{Anchoring and objectifying - mechanisms at work in the construction of the object}

An SR emerges whenever a group faces something novel and important to the group that needs to be communicated about (Moscovici, 2000). Since the group is unfamiliar with the new "object" it needs to be anchored and objectified to become familiar to the group (Jovchelovitch, 2007). The SRs rely on our memory, thus anchoring and objectifying are ways of dealing with our memory; in fact, Moscovici (2000) means that our past is constantly interpreting our present. This happens in the process of converting information into knowledge.

Anchoring can be seen as a form of assimilation where individuals fuse the foreign or unknown object into their familiar and known sphere of experience. According to Oxford Advanced Learner's Dictionary to anchor is to firmly base something on something else. Through our experiences new information is presented, which might change or modify our present SR. Anchoring is then concept formation such as the classifying and naming of unfamiliar objects or events which are parts of representation. In order to study anchoring of an SR one needs to look for the meaning behind the specific combination of elements which comprise its content.

The objectifying process makes something abstract into a concrete object. Through different types of analysis one can map the semantic world which constructs a representation and defines its structure. The importance of anchoring has been overlooked for a long period in the analysis of SRs according to Jodelet (2008). Moscovichi (2000) warned about just studying the objectifications of SR and neglecting the study of the role of anchoring.

In the process of studying an SR it seems important to identify the social arena which guides the symbolic relationships between the social actors. Hence, the meaning of an SR is entwined with or anchored in general meanings, which are specific for a certain area (Doise, 1995). The objectification of an SR is described as a more active process by Moscovici 
(2000) and unlike anchoring, it is not unanimous. These are similar processes to categorization (Billing, 1993). Therefore one important aspect of representing is attempts to discover how groups can make our world predictable.

\section{The function of SRs}

Because SRs create the basis for shared information among people, it forms the foundation for common sense theories that people hold about the social world (Jovchelovitch, 2007; Moscovici, 2000). Not only do they help us to name phenomena and understand them but also help us to make decisions about them. First, they organize social actions and communications, and second, they function like interpretation systems that influence how we approach the world and others (Howarth, 2006; Moscovici, 2000). This dual package enables people to collectively behave in response to social understandings (Moscovici, 2000). However, SRs do not explain, but describe related behavior (Wagner, 1993). Consequently, an SR plays an important role in the interaction between others and the "object" since it guides interactions with the object and provides a meaningful direction for further actions. When teachers provide and interact with students they often need to make decisions on the spot, snap decisions, while performing other tasks. The taken for granted or common sense knowledge not only automatically guides teachers' actions but also their reactions. These nonreflected reactions might be positive or negative without the awareness of the teacher.

\section{Criticism of the SRT}

Shortcomings of the theory have been put forth by researchers (Voelklein \& Howarth, 2005). A common misunderstanding treats SR as a belonging of the individual mind, as similar psychological content in the minds of different members of a social group. Billig (1993) explains that the reason for this misunderstanding is that the processes of anchoring and objectification are depicted as purely cognitive processes. However, Moscovici (2000) stresses that the origin of SR is not in individual minds but interaction and joint activities are the basis of consensus of SRs and anchoring and objectification are cognitive as well as social, cultural and ideological (e.g. Jodelet, 2008; Wagner, 1993; Voelklein \& Howarth, 2005).

Within the criticism is the issue of whether or to what extent SRs are shared. Moscovici confirms that divergent or conflicting ideas exist among members of a social group but they share concepts and frame of reference 
and the object is of importance for its members. According to Moscovici (2000), the dynamics of SRs, generated by conflict and tension, are important in their formation. It is through these conflicting ideas that existing representations are reexamined and altered (Jovchelovitch, 2007). In fact, it is through the contact with conflicting social representations that human beings become aware of their own notions and can reflect on what is unique about the representations they hold (Voelklein \& Howarth, 2005). Due to this dynamic property of SRs the risk for social determinism which was brought forward by McKinlay and Potter (1987) can be discarded as a shortcoming of the SRT.

In addition some argue that the SRT does not differ from other concepts. For example, Jaspars and Fraser (1984) questioned whether there is a real difference between attitudes and SR, an issue of importance for this thesis. They view SR as a contradictory process; from being a collective SR it becomes an attitude individualized in a person's mental operations. This criticism has also been brought forward by Farr (1993) who suggested that attitudes are social and similar to SR. Moscovici (2000) did not view this as a limitation of the theory since SR is common sense knowledge shared by a collective while attitudes are expressed in relation to that knowledge, a binary relation, thus a dimension of the SR. Therefore it is assumed attitudes are dependent on representations, but representations are only superficially dependent on attitudes. In this view attitudes would be on an individual level while SRs are on a social level (Moscovici, 2000).

Furthermore this critique is based on a view that depicts SR and practices as separate, but SRs theorists see no such separation instead they view SRs as predicting the carrying out of social practices (Moscovici, 2000; Wachelke, 2012; Wagner, 1993). This is not behavior of the individuals per se but as members of social groups (Wagner, 1993). Therefore SRT is relevant for our study of teachers and other professional groups enacting inclusion as a social group.

\section{How to capture SRs}

Constructions of meaning are extremely difficult to access and their relationship to the object and how it is communicated in interaction with others is even more difficult to discover (Barbier, 2011). This is because a representation of an object important to the educational activity consists of a mixture of conscious or unconscious scientific knowledge, practical experiences, organizational and institutional understanding which, for the most part, automatically guides teachers' actions (Ratinaud \& Lac, 2011). In the quest to understand how teachers interact with students with AS there is a need to approach the non-reflected, intuitive response to our inquiry. 
The benefit of implicit measures of attitudes in this kind of research was brought forward by Hornstra, Bergh, and Voeten (2010). They found that implicit measures are more valuable predictors of attainment of students with dyslexia than explicit, self-report attitude measures. One of the reasons suggested is that teachers may feel that it is not socially acceptable to report negative attitudes toward students with disabilities. In addition, the researchers discuss the value of tacit or implicit attitudes for understanding fast and intuitive reactions. When a teacher is busy performing different tasks this nonverbal behavior might spontaneously surface. Hornstra et al. (2010) called for a realization of the undesirable effect negative attitudes may have on students with disabilities in the inclusive setting since there is a circular relationship between attitude and representation (Moscovici, 2000). The view that attitudes reinforce representations without deciding their content is assumed in this thesis.

Kahneman and Tversky (1984) introduced the machineries of the human brain as having two levels: System 1 is automatic and fast, allowing for cognitive effortlessness without a lot of control; System 2, on the other hand involves effort and concentration, such as difficult computations. System 1 is in control most of the time, as System 2 is not so energetic. Because System 1 is quick and survives on associative memory and System 2 is slow and conscious, System 2 is mainly activated when System 1 is unable to address the issue. Humans intuitively use System 1, whose spontaneous associations grow from common stereotypes, resemblances and emotions instead of System 2, allowing their fast intuitions to take over reflected thinking. These intuitions are powerful which explains why people misconceive events and jump to wrong conclusions (Tversky \& Kahneman, 1981). In his book Thinking fast and slow, Kahnman (2011) provided several examples of how System 1 generates an answer without consulting System 2:

System 1 provides the impressions that often turn into your beliefs, and is the source of the impulses that often become your choices and your actions. It offers a tacit interpretation of what happens to you and around you, linking the present with the recent past and with expectations about the near future. It contains the model of the world that instantly evaluates events as normal or surprising. It is the source of your rapid and often precise intuitive judgment. And, it does most of this without your conscious awareness of its activities (p. 58).

These are the intuitive and tacit attitudes that we want to capture in order to gain knowledge of what, for the most part, automatically guides teachers' actions (Ratineaud \& Lac, 2011) in their attempt to include students with AS. These tacit attitudes are expressed through explicit ideas or images and give them meaning they had not previously had (Moscovici, 2000) 


\section{SRs: The central core and the peripheral system}

The goal of our social representational research is to capture both the semantic content of an SR, the organization of its content and its central core. Each individual's life history is unique hence, identical representations do not occur. However a central core of shared representations exists to allow day to day interaction between members within a community.

According to the French structural approach an SR is organized into two systems: a central system and a peripheral system (Abric, 2001; Molinari \& Emiliani, 1996; Parales Quenza, 2005). In order to describe the structure of an SR it is necessary to identity its central core, i.e. the primary organizer of the representation providing meaning and value to the other elements (Abric, 2003).

The central zone consists of the most stable elements which are likely to be part of the core of the SR. It has originated from collective experiences and memories of the social group. These elements are stable, difficult to change and founded on deeply rooted features and beliefs widely held within one's community and influence how we organize other knowledge (Moscovici 2000). They remain firm in community cultures, progressing to shape specific views of reality, and ensure the lasting nature of the representation in changing contexts (Abric, 2001; Molinari \& Emiliani, 1996; Wachelke, 2008). The peripheral system consists of less stable elements and orbits around the central core and provides space for the acceptance of new information even though its primary function is to act as a defense system of the central elements by preventing changes in the SR (Flament, 1994).

Peripheral elements are pliable and can include inter-individual differences and new information such as personal experiences and adapt it to the moment which may lead to adaptation or transformation of the surrounding environment (Guimelli, 1993; Moliner, 1994). However, transformation of a representation can only be possible if the central core itself is doubted (Moliner, 1994).

Describing the structure of an SR requires the identification of its central elements which are robustly resistant to change and communication pressure (Abric, 2001; Wachelke, 2008). In this research, the structural approach is adopted to identify and analyze SRs of students with AS and their inclusion. By applying this approach the formation and evolution of SR in the course of history can be explored. SRT claims a deep link between cognition and communication and between mental operations and linguistic operations. Through these operations SRT has been able to explain the formation and evolution of practical knowledge as well as their social function (Moscovici, 2000).

The structural view can be applied in research by comparing elements of SRs of different professional groups (e.g., teachers, principals and health 
professionals) to identify similarities and differences between teachers and teacher subgroups. These can be described as professional representations (Ratinaud \& Lac, 2011). A core-periphery analysis is used in this research to provide a structural view of the SR of the inclusion of students with AS. While SRT helps us to develop our findings, notions regarding behavior provide a strong rationale for bridging the mismatch between these different professional groupings. 


\section{Teachers' representations of inclusion}

In our attempt to generalize the application of categories such as AS, we need to consider the difficulty teachers might have when adapting to new policies compared with the pre-existing ones. In spite of the "new" reforms there is a general tradition to subscribe to the medical paradigm which views disability as a deviance from the norm (Westling Allodi, 2007). Teachers play a vital role in providing meaningful learning situations and adapting for students with AS (Parsons et al., 2011). Students need to achieve educational objectives and authorities have provided guidelines for inclusion of students with specific needs. We do not fully know why some teachers are reluctant to include students with AS. Nor do we not know why some teachers are not entirely supporting the objectives of inclusion. Teachers may have knowledge that it does not work or that it is the best approach. Demographic variables such as gender and previous teaching experience have been shown to impact inclusive beliefs (Loreman et al., 2007).

This is all in accordance with Moscovici's (2000) statement about our history being part of everything we say and do in our daily life without us being aware of its effects on our experience. He argued that our culture and history control our present reality though we are unaware of their potent power. According to Moscovici (2000) there is drama involved in the process of transformation of knowledge and the birth of a new SR. In the school context there is always a need to adapt, to get along, and to master our environment both intellectually and physically. Thus, conflicts are associated with new SRs and can be seen as a spin off effect within the field of education as they help to establish a new order in the environment and make communication easier through codes and social categories (Moscovici, 2000).

Moscovici recognized the power of representations but saw in SRs a struggle between innovation and tradition, between conformity and rebellion (Moscovici, 2000). The Salamanca statement can be viewed as an example of this struggle. It places demands on adapting pedagogical activities and attitudes while schools are struggling with consensus and contradictory views and has not yet been entirely successful in its implementation (Hausstätter, 2014). By providing for students and through interactions, teachers incorporate and co-construct SRs on various aspects of their professional life in school (Jodelet, 2008). In order to understand why inclusion is not maximized it is important to know what SRs teachers establish of "the other" (the object), that is, students with AS, and their SR of inclusion of students with AS. In sum, in accordance with Moscovici and SRT, teachers' 
representation of students' differences lead to different educational consequences affecting inclusion. Therefore there is a need to ask: Do teachers define these students' problems as deficits or needs inherent to the individual or are they related to a dysfunctional school environment or a combination of the two? The answer to these questions is of great consequence in this dissertation since SRs can be seen as guides to how teachers unconsciously/consciously include students with AS.

\section{How to capture teachers' SRs of inclusion of AS}

The adoption of the SR approach changes the perspective from which we may look at teachers' conceptualization. Often the beliefs and attitudes are explored in isolation from their context. In this dissertation it is the SRs of teachers that will be explored and related to the social and cultural context of the school in order to understand how the inclusive practice is realized. The impact of certain factors on teachers' SR will be measured by looking at sex, level of teaching and time-point of teacher training, experience, special training and self-reported competence.

Therefore, in order to make sense of teachers' beliefs and attitudes toward inclusion of students with AS, this dissertation leans on a theory that combines SR, actions and reactions and examines and analyses them together. In doing so this dissertation focuses upon teachers' common sense knowledge of students with AS and inclusion of students with AS.

In short, SR gives an answer to the following questions (Jodelet, 1996):

- Who knows and from where do we know?

- What and how do we know?

- About what do we know and what are the consequences?

These questions will present a framework for this research which takes into account historical conditions in interpreting and understanding the mechanisms behind teachers' SR and to some degree school leaders and student health professionals' SRs of inclusion of students with AS. By exploring teachers' tacit knowledge, understanding of the teacher experience and expectations of having students with AS in the general classroom will be enhanced so improvements to make schools more inclusive can be proposed.

\section{Aim}

The purpose of this study was to increase knowledge about teachers' social representations of students diagnosed with Asperger syndrome and their 
inclusion in the general classroom. Hence, the overall purpose of this dissertation was to:

1. Illuminate and analyze school staff's and specifically teachers' SRs of students with AS and their inclusion in order to shed light on their approaches to inclusive teaching.

2. Explore what teacher factors predict positive attitudes towards inclusion of students with AS.

The specific aims of the four studies were:

Study 1 To elucidate teachers' SRs of students with AS and to explore in what way the level of teaching, the sex of the teacher and the time-point of teacher training are related to their SRs.

Study 2 To explore the relationship between experience and teachers' SRs of students with AS and to elucidate to what extent experience makes a difference in teachers' SRs of students with AS, if work-related experiences of AS impacts teachers' SRs and if private experiences of AS influence teachers' SRs of students with AS.

Study 3 To study and analyze SRs held by teachers, health professionals and principals with regard to the inclusion of students with AS and specifically explore the content and structure of the SR and compare principals, SHPs and teachers with regard to these aspects.

Study 4 To explore what teacher factors predict positive attitudes towards inclusion of students with AS. 


\section{Empirical Studies}

\section{Methodological choices}

Many methods can be used in studying SRs. Since the overriding aim was to understand how teachers and other school staff make sense of and assign meaning to students with AS and to the concept of inclusion of students with AS, a qualitative method was required. In order to explore their meaning of inclusion of students it is feasible to conduct interviews, however, one of the aims of this research was not only to grasp the semantic content of an SR but also its composition and organization. In line with the French structural approach, the structure of an SR is not a simple collection of elements, but the connections between and integration of these elements (Lahlou \& Abric, 2011; Molinari \& Emiliani, 1996; Parales Quenza, 2005). Identifying the links of the elements is not viable using interviews. However, different approaches have been developed for singling out central elements and their network. Defining the structure of a SR requires the discovery of its central zone (Abric, 2001).

The basis of the central and peripheral system is a set of cognitive elements, detected by a free evocation task (Bodet, Meurgey, \& Lacassagne, 2009; Ferreira et al., 2006). Therefore, the method in this dissertation was based on the use of free associations. This approach penetrates the covering of responses that participants typically might provide through a traditional interview process but it permits a larger number of participants and is less vulnerable to desirability bias.

Another advantage of using free associations is that it is less structured and more open-ended than most traditional survey methods. For example it is not influenced by pre-specified answers as is the case in most questionnaires. At the same time it offers some of the advantages of the questionnaire, such as the ability to gather large amounts of computable data. The identification of a central zone demands not only the extraction of its central elements, but also mapping the links among these elements. (Abric 2001; Molinari \& Emiliani, 1996; Wachelke, 2008).

\section{Free association method}

Free association is a technique used to penetrate a person's unconscious thoughts and feelings, that is, to capture their fast and automatic system one response (Kahneman \&Tversky, 1984). The goal of free association is 
primarily to identify thoughts and feelings about life situations that might be problematic, yet not self-evident. The method of exploring a person's thoughts by eliciting words or phrases that are associated with key words provided is thought to be fast, effortless and largely automatic. Thus, free associations allow us to access the latent dimensions which structure the semantic universe of the term or object (phenomenon or event) being studied (Ferriera et al., 2006; Lahlou \& Abric, 2011; Moloney, 2010). In order to describe the subjects' SR of the "object" it reveals the elements from the responses acquired from the association task (Abric, 2001; Moscovici, 2000).

The semantic analysis captures the content of SRs but it cannot be used to make conclusions about the process that generates social knowledge (Lahlou \& Abric, 2011). It is difficult to describe a representation but most approaches of SR agree on their double nature of process as well as content (Moscovici, 2000). However studies tend to describe the representation by their content only (Lahlou \& Abric, 2011). By employing the association method it is feasible to uncover the structure by exploring relations between the elements and revealing their relations to other elements. In addition the process through psychological operations, e.g. recognition, categorization and sense-making, when addressing a given phenomenon will take place. It is the result of that process, in the form of some "presentation," or image by which the object or phenomenon is re-presented by the subject.

\section{Prototypical method}

The central system is the very basis of the representation and has its foundation in the consensus and the cultural and psychological homogeneity of a group. Since the frequency of an element is not necessarily the most reliable indicator of its central status, this indicator does not seem to be sufficient (Abric, 2001). The central status of an element is not limited to its quantitative dimension but also includes a qualitative dimension (Ferriera et al., 2006; Lahlou \& Abric, 2011). In other words, it is not only the frequency of an element which defines its centrality but how it is related to other elements by the subjects (Moliner, 1994; Wagner et al., 1999). In this way, as illustrated in figure 1, four zones of centrality can be determined. Likewise, this tracking allows for structure (hierarchy) and assumptions on whether the elements are related to the central zone or peripheral systems of the SR (Mäkiniemi et al., 2011). 


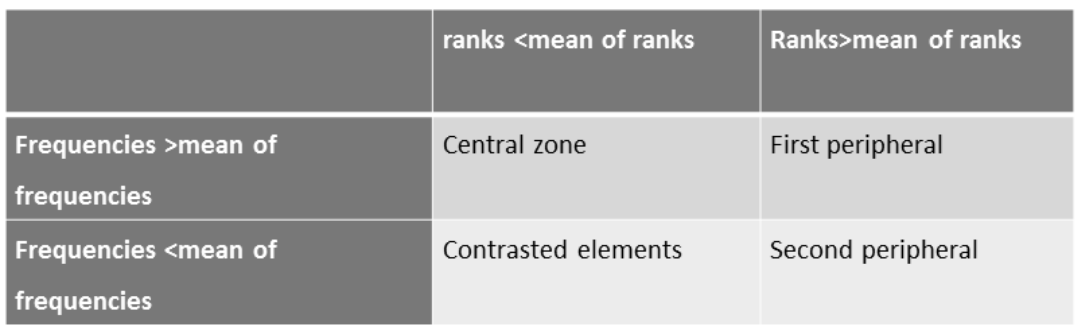

Figure 1.Matrix of hierarchical structure of associations showing the four zones

\section{Similarities (co-occurrence) method}

The network analysis is a set of tools introduced by social network analysis techniques and graph theory (Bales \& Johnson, 2006). The pair-wise interacting associations in networks are agents such as people, words, concepts etc. (Coronges, Stacy, \& Valente, 2007; Solé Corominas-Murtra, Valverde, \& Steels, 2010. Coronges et al. (2007) found that associations had a different structure across groups and suggested networks for analyzing associative structures in different populations. By defining elements as nodes (circles) and the co-occurrence as lines, a network for analyzing the structure of SR was developed. For example, in the word association task, a participant is asked to associate to a stimulus phrase. A line is assigned between connected evocations. The net-work is displayed in a graph, which presents the spatially strongest co-occurrences between pairs of elements thus reflecting the most intensive relations between the phrases (Coronges et al., 2007; Wiles et al., 2010). The most important nodes (circles) are by nature the hubs of the network. A hub is thus an element with a disproportionately high number of connections to other elements. The large-scale complexity of these networks is reduced to bare bones to make the networks or graphs conceptually simple (Bales \& Johnson, 2006) 


\section{Data collection}

\section{Participants}

The participants consisted of 170 teachers working in mainstream schools in six municipalities in the central part of Sweden. To make structural comparisons 27 principals and 39 school health professionals (SHP) from the same schools also completed the questionnaire. Among the SHPs were psychologists, school nurses, social workers, SENCOs, special needs teachers and study and career advisors. The average age of the principals was 52.6 ( $\mathrm{SD}=7.9, \mathrm{Md}=53)$, for the SHPs $54(\mathrm{SD}=7.9, \mathrm{Md}=54)$ and for the teachers $47.3(\mathrm{SD}=10.3, \mathrm{Md}=46)$.

Table 1. Teachers' sex, level and years of teaching experience and whether they are qualified/not qualified $(N=170)$.

\begin{tabular}{|l|l|r|}
\hline Participants & \multicolumn{2}{|c|}{ N } \\
\hline Sex & Male & 35 \\
& Female & 130 \\
& Unknown & 5 \\
\hline Level of teaching & Female & \\
Kindergarten-3 & $100 \%$ & 43 \\
$4-6$ & $90 \%$ & 30 \\
$7-9$ & $66 \%$ & 32 \\
High school & $61 \%$ & 46 \\
Other & & 29 \\
\hline Recently trained & $17 \%$ & 29 \\
\cline { 2 - 3 } Earlier trained & $78 \%$ & 132 \\
\cline { 2 - 3 } Unknown & $5 \%$ & 9 \\
\hline Qualified/ & $91,2 \%$ & 156 \\
not qualified & $8.2 \%$ & 14 \\
\hline
\end{tabular}




\section{Questionnaire}

A web-based questionnaire was developed for the investigation based on earlier studies in disability research on teachers' attitudes towards inclusion of students with disabilities (Jerlinder, Danermark, \& Gill, 2010). It consisted of two association tasks and demographic data: age, sex, teacher training, years and grades of teaching and experiences with students with AS. The questions as well as the technology were pilot tested on 12 people, 10 teachers, 1 principal and 1 special education teacher, however, no changes needed to be made to the questionnaire.

The participants were asked to produce associations in response to a given cue. In this task, the participants were provided with two stimulus phrases and then asked to respond with the first words or phrases that came to mind. Figure 2 gives an overview of participants, method and analysis.

\section{Procedure}

Teachers and other school staff from six municipalities in the central part of Sweden took part in the studies that make up this thesis. Initial contact was made with the school administrator of eight municipalities to present the project and to get approval of this research. Two school directors declined citing the high workloads of teachers who were busy adapting to new curricula, courses and a new grading system since the new Swedish Educational Act (2010: 800) had just been implemented. Another reason for not participating was that schools were already involved in extensive research projects.

A web-based questionnaire was sent out by school administrators in the different municipalities by whom the study was approved. Teachers, principals and health professionals were invited to participate by these administrators and were provided a link to the website where the questionnaire could be completed. When the different school staff linked into the website, they were asked to complete individually an association task. In addition, the questionnaire had some demographic questions such as sex, education, level and years of teaching. The stimulus phrase "student with Asperger diagnosis" was presented as the first cue and participants spontaneously wrote, in their own words, up to five words or phrases. After spontaneously producing phrases, the respondent was asked to reflect upon the phrases and rank them from one to five; one being the most important and five the least important regarding student with AS. Next, the respondents were asked to give the valence, that is, whether the meaning of each phrase they had produced had a very positive $\left({ }^{++}\right)$, positive $(+)$, neutral $(0)$, negative $(-)$ or very negative (--) tone. The next association cue was "inclusion of students with Asperger diagnosis" where the participants again were asked to 
write up to five phrases, rank them accordance to their importance and assign them valence. These open questions were first in the questionnaire so the demographic questions would not interfere or influence answers. The concept of inclusion was given as self-evident to the school staff in the collection of empirical data. Only one teacher inquired about the implied definition of the concept via e-mail. After the two SRs tasks were completed, the background questions appeared one at a time. When participants had completed the questionnaire, the answers were anonymously saved. A total of 236 questionnaires were completed individually and returned electronically.

Subsequently the associations produced were recorded and categorized. The resulting pattern of associations helped illuminate and outline the distribution of an SRs' semantic field, as well as its basic features and central/peripheral system. This knowledge about the features of an SR is important in order to be able to understand its meaning and its stability.

An overview of the studies including their main focus methodology and participants is provided in Table 2.

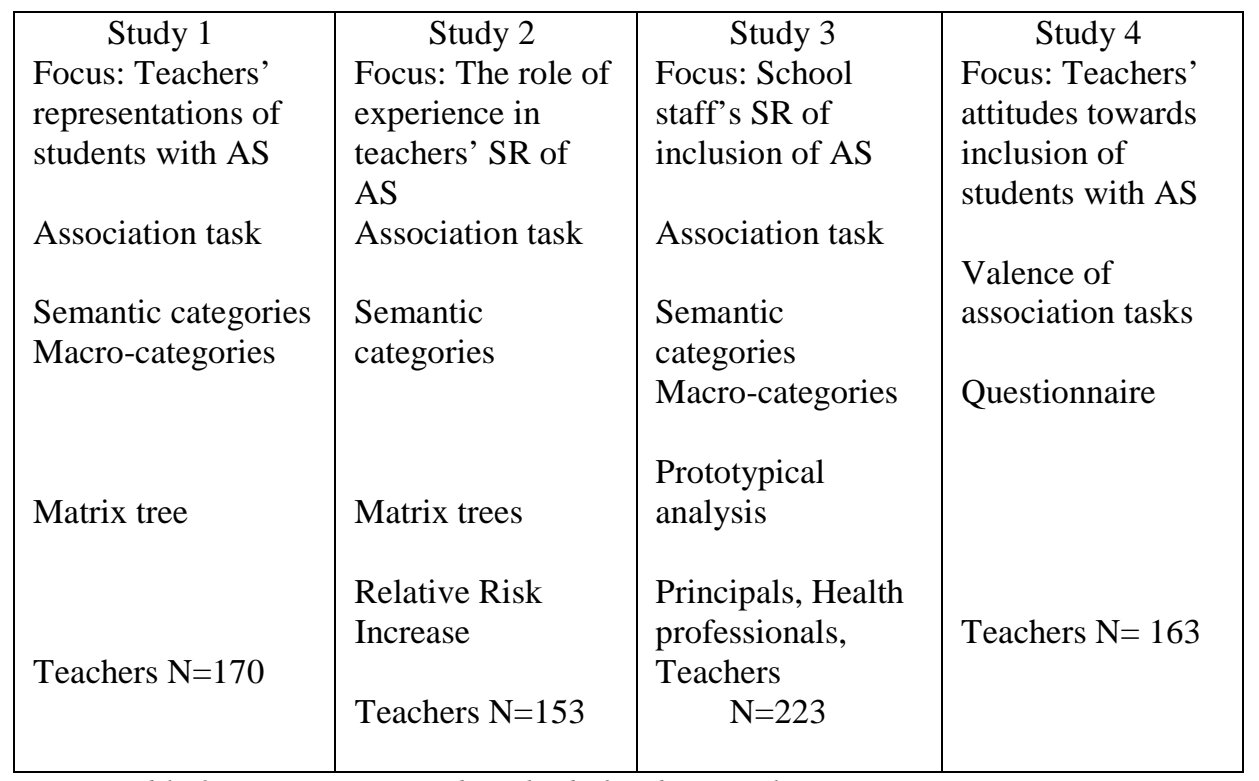

Table 2. Participants and methods for data analysis 


\section{Ethics}

Research involving people is regulated by ethical considerations. The approval for the project was received from the school authorities in the six municipalities. The participants in this project received an invitation to take part in the project through an e-mail from their school administrator. They were informed about the specific purpose of the project and the empirical data has been used accordingly. By clicking on a link the participants accepted the offer to participate in the study. Information about the project, name of researchers and contact person was included in the e-mail. Three people contacted the researcher about specific issues. The data for these studies were collected with a survey (survey monkey) from school staff. Participation was completely anonymous and the research team did not record or have access to names, addresses or the IP of the computers used. The research team also ensured confidentiality by presenting the results on a group basis. The research process followed the ethical principles of the Helsinki Declaration (WMA, 2013).

\section{Data analysis}

The methods used to analyze the obtained data in this dissertation fall into descriptive techniques. Two techniques have been used that have been especially developed for analysis of SRs. They are prototypical analyses and analyses of similarities (see below). In addition, other more standard statistical tools were used to analyze SRs in Excel and SPSS.

First, the data were analyzed through categorization in several steps. The first step used a qualitative approach to explore and categorize the free associations delivered by the participants. Phrases that expressed the same semantic content but differed in form, e.g. singular/plural definite/indefinite forms, were grouped together. Synonyms and phrases that were semantically equivalent were put into the same category, for instance the category named 'lack of executive functions' contained words or phrases like: lack of impulse control, difficulty starting and completing tasks, unfocused, and lack of logical thinking. Two researchers and two teachers examined the words and phrases and put them into categories. This was done by reducing the number 
of categories which gradually emerged into broader categories. Here is an example of the different steps:

Students' acceptance of differences

Tolerance

Peer interaction

Classmates' understanding

Patience of peers and staff

Understanding

Ambient understanding

When there was a discrepancy in classification, the item was discussed and a fifth person was consulted. In this way, we obtained consensus as to the classification of the phrases. However, four associations (what, how, ok and need) for students with AS and ten for inclusion: (reason, needs (2), individualism, presence, tempo, ?(4)) were left uncategorized and omitted in further analyses.

In step two, the valence of the given word/phrase was identified and used for categorization. This sometimes produced dichotomous categories. A negatively valenced term within one and the same category would at times make a category of its own, for instance, the items that were negatively charged within the category 'structure and routine' formed the category 'need for structure and routine.' The categories that emerged then went through additional analysis. The categories were translated from Swedish to English and back-translated to Swedish. Discrepancies were identified and resolved by discussing with native speakers.

\section{Analyses of similarities (co-occurrence)}

First, co-occurrence of the semantic categories, from now on referred to as micro-categories, are visually presented in order to identify the structure and hierarchy of the micro-categories by using the software program Iramuteq (Ratinaud, 2009). This program is an r-based interface for multidimensional analysis of texts. It is specifically developed and designed for data processing of words and phrases. Second, analyses of similarities tend to be used in order to examine the organization of SRs and changes in them. The visual distribution of the different sized categories and the links between them is called the maximum tree. The maximum tree shows how the microcategories are connected and defines a core of the representation (Abric, 2001; Alves-Mazzotti, 2011). These trees are presented in the full appended articles 1 and 2 . The data analyses, the co-occurrence ties between the categories are measured and presented showing the links among pairs of categories. The lines represent the value of the corresponding co-occurrence index. However, representing the entire matrix on this type of graph will 
make an interpretation difficult and give redundant information. Thus, it is necessary to extract the simplest tree or graph that accounts for the most possible co-occurrence (Solé et al., 2010; Wiles et al., 2010). The thickness of the lines is in proportion to the number of co-occurrences and the size of the circles was in proportion to the number of mentions but only to a certain degree; the largest circle was 10 times bigger than the smallest one which supplied the proportional.

\section{Prototypical analysis}

A prototypical analysis was conducted in study 3 . This provides a measure of the organization of the elements, and was carried out to reveal the structure of the SR which is defined as the central zone and the peripheral system (Abric, 2003; Wachelke \& Wolter, 2011). This was performed by applying to each of the semantic categories the double criterion of frequency of occurrence and rank which, according to Abric (2003), combines the total number of evocations of each category with an individualized or subjective criterion, that is, the importance the category is given in the task performed by each participant (Harma et al., 2013; Mäkiniemi, Pirttilä-Backman, \& Pieri, 2011). The aim of this analysis was to identify the content structure of the associations which is an important aspect of identifying their SR. The rank for each response was computed from 1 , the most important evocation, to 5 , the least important of the evocations. The underlying principle of this double analysis is that categories more frequently mentioned and given a higher rank are more prominent, and hence more likely to belong to the central zone of the SR (Abric, 2003).

\section{Studies}

\section{Study 1}

Aim : To elucidate teachers' SR of students with AS and to explore in what way the level of teaching, the sex of the teacher and the time-point of teacher training are related to their SR.

Analysis: In addition to general data methods described above, macrocategories were formed in order to get an overview and a clearer picture of the components shared by the 'micro-categories' of students with AS. Therefore, the categories were grouped together using a combination of the 'micro-categories' and criteria for macro-categories. The research team affirmed the reliability of the grouping of categories into macro-categories. 
This approach and organization of the data allowed for an analysis of the micro- and macro-level and thus a more qualitative manner. This was calculated in Excel, and a $\chi^{2}$ test was performed.

Analyses of similarities were performed where the categories were visually presented, co-occurrence of micro-categories, in order to identify the structure and hierarchy of the micro-categories.

The results revealed that teachers do indeed share an SR of students with AS which corresponds to Wing's triad of the disorder relating to deficiencies in social interactions, intellectual profile and special interest (Wing, 1981). The central elements reflected an approach where the problems are related to dysfunction within the individual. A third of the associations were related to the environment and educational provision. As suggested by previous research (e.g., Demetriou et al., 2009), teachers' sex, level and years of teaching were explored and the representations were analyzed in the context of these variables. An apparent gender difference among the teachers surfaced where male teachers were more inclined to adapt the school environment to students with AS while female teachers were more concerned with the needs and well-being of the student. Also there was less focus on disability but more on the adaptation of educational practices among recently educated teachers. In addition, more recently trained teachers were more inclined to relate to adaptations of the school environment.

\section{Study 2}

Aim: To explore the relationship between experience and teachers' SR of students with AS and to what extent experience makes a difference in teachers' SR of students with AS, how work-related experiences of AS impact teachers' SR of students with AS and private experiences of AS influence teachers' SR of students with AS.

Analysis: The frequency of occurrence of the semantic categories concerning students with AS was calculated in Excel, and a $\chi^{2}$ test was performed. In order to compare the groups we studied their relative relationship between the categories. In presenting our empirical findings, we used the relative risk increase (RRI) to describe and compare which categories were most frequent. RRI was used for computing event rates of the groups which had different baselines. Here, the base group (P1) was the group of teachers with experience, while the reference group (P2) was the group of teachers without experience. The relative risk ratio was expressed as a percentage. 
Analysis of similarities was performed as an in-depth analysis in order to identify and compare the structure and hierarchy of the micro-categories among groups of teachers.

Results: Teachers with experience were generally more positive to students with AS, their SR elements related more frequently to the environment and learning factors while teachers without previous experience more often related to the individual student's behavior. However, those with private experience and an assumed more intimate understanding of the possible special needs of students with AS, were less positive.

\section{Study 3}

Aim: To explore and compare the SRs of inclusion of students with AS among teachers, principals and SHP.

Analysis: In the first step, the frequency of occurrence of the semantic categories concerned with inclusion of students with AS was calculated in Excel.

In step two the researchers formed macro-categories of micro-categories with similar components. The micro-categories containing educational aspects of teaching and learning formed the macro-category "educational aspects." Micro-categories that expressed problems such as "a burden" and "barriers" in conjunction with inclusion were grouped together in a "negative" macro-category while micro-categories that expressed positive aspects such as "equality," "opportunity" and "importance" in conjunction with inclusion formed a "positive" macro-category. The micro-categories that referred to the school organizational level such as "lack of resources," "support" were put in the macro-category "organizational aspects" and micro-categories referring to the environment such as "adaptation of the environment" and "ambient understanding" were put in the macro-category "environmental aspects." The micro-category "individual different potentials" referring to the individual's capacity, strengths and weaknesses did not fit any other macro-category and thus formed its own macro-category.

In step three a prototypical analysis was performed by applying to each of the semantic categories the double criterion of frequency of occurrence and rank. To explore the hierarchical structure the software Iramuteq was used (Ratinaud, 2009) which computes the frequency and rank of each category. We performed a statistical analysis of the semantic categories, valence and the macro-categories. Taking the school staff as the dependent 
variable we ran a $\chi^{2}$ test exploring whether there was a significant difference between the three groups.

Results: Since SRs are group-bound constructions we expected a difference among the different professions in the school arena. Indeed, the study results indicated that teachers were more positive to inclusion than other groups of school staff. Principals focused more on environmental aspects whereas SHPs emphasized students' needs and their individually different potentials while, at the same time, brought up the importance of adaptation of the environment and educational strategies.

\section{Study 4}

Aim: To survey factors related to teachers' confidence towards including students with AS and to explore what factors predicted positive attitudes towards inclusion of students with AS. The background factors included were: sex and age of the teacher, years and levels of teaching. The professional variables included were attitudes toward students with AS, perceived knowledge, competence, experience and special training.

Analysis: Data was entered into the Statistical Package for the Social Sciences (SPSS version 22). First the valence rating of the association task for inclusion of students with AS was identified and calculated. A mean score for self-reported ratings of each teacher predictor variable was calculated. Correlation tests were performed in order to reveal possible relationships between the valence ratings of the associations that emerged for the two cues. Pearson $r$ correlation coefficient was calculated for teachers' valence ratings toward students with AS with teachers' valence ratings for including these students in the classroom. Correlation tests to reveal possible relationships between the valence ratings of the associations that emerged for the two cues were conducted. Pearson moment correlations were conducted in a matrix to explore the relationships between the variables and teachers' views of inclusion of students with AS. Independent t-tests were performed to examine the mean differences between the different groups of teachers.

Results: The study revealed that teachers' attitudes towards the inclusion of students with AS were mostly positive and correlated with their attitudes toward students with AS. Teachers of lower grade levels were less positive to inclusion of students with AS than were teachers of higher grade levels. Positive attitudes towards inclusion of students with AS were related to teachers' knowledge about methods for teaching students diagnosed with AS and their view of the individual. 


\section{General discussion}

This dissertation focused on teachers' SRs of inclusion of students with AS. This is essential since teachers are key actors in the school system (Hattie, 2012; Whannell \& Allen, 2011) and their beliefs and attitudes also play an important role in their interaction with students with AS and their provision for them in the general classroom. This dissertation was guided by SRT - a theory used to explore how our SRs merge in action and behavior. It is important to be aware of the fact that SRs do not influence the way we think, rather, how and what we think depends on our SR. By exploring teachers' SRs, their shared common sense knowledge, the goal was to further close the gap between inclusion and exclusion since inclusion is an unfinished, ongoing process (Haustätter, 2014).

Taken together these four studies highlight teachers' SRs and provide impetus for better provision for students with AS.

In this discussion the results will be summarized and placed in the framework of SRT. Thereafter methodological issues of the dissertation and future research will be discussed. Finally conclusions and implications will be provided.

\section{Findings in relations to the theoretical framework}

In the following the findings will be articulated through the theoretical framework of SRT (Moscovici 2000). This will be done in light of the questions posed by Jodelet for analyzing the participants' SRs (Jodelet, 1995). The first part will attend to the identification of the subjects of SR, the teachers and further, teachers' collaboration with the structural level will be discussed. In the second part, the objects for SR, which were students with 
AS (studies 1, 2) and inclusion of students with AS (studies 3, 4), and the anchoring and objectification will be analyzed.

\section{Teachers -the subjects of the investigation of SRs}

\section{The classroom level}

To understand the teacher as a subject in the social psychological approach characterizing SRT, teachers may be viewed as co-workers in building knowledge with their peers and not solely as a passive recipient of such knowledge. It is through this common sense knowledge that teachers' work can be analyzed with respect to the student diagnosed with AS. Given that teachers' SR and their actions merge, their behavior can be assumed (Harma, et al., 2013; Jodelet, 2008; Moscovici, 2000).

While teachers' SR of students with AS is cautious (Study 1) the findings showed that teachers' SRs towards the philosophy of inclusive education are typically very positive (Studies 3,4 ). The findings provided significant insights into how the inclusion construct has been realized in classrooms for students with AS since there is a high degree of consensus with the medical explanation among the teachers, hence it is well established and accepted. Expressed differently, the neuropsychiatric category of AS can be seen to presume that the difficulties of the specific student are pre-given, i.e., they are believed to exist independently of the school environment. One way of interpreting this is to consider the fact that teachers want a deeper understanding and believe that they do not have enough knowledge, a view also discussed by the School Inspectorate (2012) and Nilholm et al. (2013). This was also indicated in the fourth study where teachers' self-reported lack of special training for teaching students with AS was pronounced which was also concurrent with previous international research (Jordan, 2005; Mavropoulou \& Avramidis, 2012; Moores-Abdool, 2010).

There were noteworthy teacher demographics that influenced teachers' SR in Study 1; namely the sex of the teacher and time point of teacher training. While a previous Swedish study found no correlation between a teacher's sex and attitude toward inclusive education (Jerlinder et al., 2010) other international studies have found female teachers to be more in favor of inclusion than male teachers (Avramidis et al., 2000; Forlin et al., 2009). Contrary to this, we found that male teachers were more prone to adapt the school environment to these students than their female counterparts who tended to focus more on needs and disabling aspects. This discrepancy might be due to the method used in our studies which had a different approach from previous cited research. In our study implicit assumptions were explored while in previous studies explicit assumptions were brought to the surface. 
Female pre-service teachers have been found to have higher levels of sympathy (Carroll et al., 2003) and as pointed out by Homstra et al. (2013) it may not seem acceptable to express negative attitudes towards students with disability but instead they come through in our SR where tacit knowledge is revealed. This has been brought forward in previous research concerning people with disability in general (Hein et al., 2011) and even when the Implicit Association Test (Greenwald et al., 2009) has been used (Wilson \& Scior, 2014).

We aimed to study differences in the way male and female teachers view these students and how they are best supported. Since $72 \%$ of the teacher population is women in Sweden (SALAR, 2010) differences between male and female teachers have important implication for practice (Haase 2008). Research has shown that male teachers in general are much less likely to refer students with different kinds of problematic behavior to special education units, instead attempting to support them in the general classroom (Abikoff et al., 2002; Coles et al., 2012; McIntyre, 1990). We found that male teachers tended to be more concerned with adapting educational the environment which indicates that students might miss out on accommodation of the school environment to a certain extent. On the other hand, male teachers might not be as apt to realize the needs these students might have as female teachers do. This was in line with previous research which has shown that there seems to be an asymmetry between the sexes in behavioral action for example, males are more prone to problem solve while females are more concerned with emotional and psychological aspects (Wehmeyer \& Rousso, 2006; Wismath \& Zhong, 2013). This was in agreement with recent studies by Demetriou et al. (2009) who found that male teachers more often engage in the subject matter to motivate students while female teachers are more focused on students' well-being. Of course these patterns are generalizations that can only make us expect certain tendencies, but one can, strictly speaking, make predictions. The AS diagnosis is more frequent among boys where three out of four who receive the diagnosis are boys and recent research indicates that boys with the same levels of autistic-like traits more often than girls meet diagnostic criteria for AS (Dworzynski, 2012). We can only speculate whether more/less students with AS would be in separate units if there was a balance in the sex of the teachers at schools or what impact a more equal gender balance would have on inclusion. In addition, more recently educated teachers were more prone to relate to adaptation of the environment which can be interpreted as an increased awareness of the varied approaches and strategies needed for this group of learners.

We found that there was a correlation between teachers' previous experiences with AS and their SR (Study 2). Teachers without experience of individuals with AS focused more on behavioral manifestations and deficits, 
which was not consistent with the notion of enhancing inclusion (Gibbs, 2007). Bain, Brown, and Jordan (2009) highlighted the risk that teachers without experience form a biased image, therefore educational opportunities are especially important since they can be influenced by information found on the internet, on television, and in printed media, leaving them with the challenge of distinguishing incorrect from correct information. This is in line with SRT which underscores the media's role in forming SRs (Moscovici, 2000).

Teachers with work-related experience are generally more positive to students with AS than teachers with private experience. Experience appears to be shaped by their view of AS through contact with peers and students (Cooper, 2011; Soles et al., 2008); this contact might provide teachers with strategies and self-confidence. Another aspect is that private experience has generated negative experiences more obvious in the home setting and results in cautiousness among these teachers. For example, students with AS may have emotional outbursts, anxiety, depression which is evident in the home but not the classroom (Attwood, 2007). As stressed by previous research, the knowledge gained in the private sphere can provide us with a more ubiquitous experience that influences inclusion (see for example McGregor \& Campbell, 2001; Starr \& Foy, 2012). However, private experience may provide more realistic expectations about what is required to support students with AS in the general classroom (Forlin \& Chambers, 2011). In addition, the results suggest that there is a tendency to view inclusion as a burden.

In Study 4, the results showed that teachers' self-reported initial or inservice education about teaching students with AS was unsatisfactory. However they seemed to experience their competence as satisfactory for teaching students diagnosed with AS. This contradiction is important to explore. The majority of the teachers (70\%) had a positive attitude toward inclusion of students with AS, however more than half of the sample was cautious towards students with AS. This can be interpreted in different ways. One way to interpret the results is to assume that teachers know what is expected from the steering documents but see this accommodation in their practice as problematic. Another possible interpretation is that teachers focus on implications for the individual student while for inclusion of students with AS, teachers allude to a community and global perspective on human rights.

Teachers of lower grade levels were found to be less positive than teachers of higher grade levels. This was contradictory to previous findings where teachers' ambivalence about inclusion increased as they needed to be more subject focused (Avramidis \& Norwich, 2002). It was also viewed as a conflict between academic outcome and implementation of the inclusion policy requiring diversified instruction (Florian \& Rouse, 2001). However, research has shown that schools that are inclusive develop unique ways to 
adapt to diversity and may have high academic standards (Dyson et al., 2004; Jordan et al., 2009). There are different ways of interpreting these discrepancies. Teachers of lower grades spend more time with students in general such as recess and non-academic activities as well as on social and behavior management. Teachers at higher levels will have less time but more subject focused contact with students in general. In addition, students might have acquired better capacities to benefit from inclusive environment as they gain more experience and strategies to get along in the school setting (see Jordan, 2008).

\section{Teachers' collaboration with the organizational level}

As suggested by national researchers (e.g., Berhanu, 2011; Linqvist \& Nilholm, 2013; Nilholm, 2008), the link between teachers' individual practices and broader institutional forces towards an inclusive environment was investigated in study 3. Since SRs are group-bound constructions we expected small differences among the different professions. According to SRT, every public issue has different representations (Bauer \& Gaskell, 2008) and this was particularly relevant in this investigation given that the official documents, such as the Salamanca statement, suggest that the school staff should have similar views on inclusion (UNESCO, 1994). Indeed, we found that teachers were more positive to inclusion and social equality than other groups in the school environment and more often referred to students as assets and their right to participate.

\section{Principals}

The results indicated that principals focused on environmental aspects and less on learning and teaching activities which are at the foundation of all educational activities or schooling. This finding needs to be discussed in terms of not seeing the forest for the trees. Do our professional roles take over or do they even replace an overall vision?

There are of course different agendas for the different professions. If the principals are mainly concerned with the organization and structural level alone a way to bridge the gap to the classroom and individual student level may not be developed. This could also be disastrous for the development of continuing education and in-service training for teachers and other staff since the principal is responsible for educational improvement of personnel and also the distribution of resources. Research conducted in Sweden (see for example Berhanu, 2011; Nilholm et al., 2013) has stressed the importance of 
leadership for school improvement and for the development of an inclusive educational environment. These studies have suggested that the one way to reduce barriers and guarantee successful development for all students is to find a model for collaboration. Study 3 found that the professional groups shared a representation through the central elements, the non-negotiable elements, but they differed in their peripheral elements which was typical for different professions where the specifics favor their "own business."

In a broader social perspective this phenomenon is not surprising considering that SRs are in fact historically and culturally dependent (Jovchelovitch, 2007; Moscovici, 2000). Traditionally heads of school have not been involved in classroom activities but have been part of a hierarchical system while monitoring teachers' performances and they still have power and control within the school arena. There are power relations to be considered. While there have been major changes in the nature of principals' tasks and duties they are still responsible for assessing teachers' performances and deciding on their work load and pay.

\section{SHPs}

In order to initiate and monitor good practices in the classroom, SHPs serve as the experts in the field. In fact, the team of experts plays an important role as the advisers of policy practice. The role of SHPs among other tasks is to assist students' need for adaption of the school environment, establish individual study plans, help and support teachers' work in the inclusive classroom and sometimes direct students from the general classroom into special education units. Consequently, in their work, school professionals will most likely advice teachers and/or principals of educational provision for these students. Thus among professionals, advice/recommendations are crucial to the realization of carrying out an inclusive environment in mainstream classrooms (Cowne, 2005; Lindqvist, 2013; Sharma et al., 2008). The role of SHPs and especially SENCOs (special education needs coordinators) can be seen as change agents who work for improving teaching and learning for all students collaborating with the structural level. Evidently, as our results showed, they were more reluctant to inclusion of students with AS than the other professions. How are we to understand this implication?

This can be attributed to the fact that schools are not fully equipped with SENCOs and other health professionals. Since the use of SENCOs is fairly new in Swedish schools they may not have the time or mandate to work proactively as change agents since their role is not clear cut (Lindqvist, 2013; Linqvist et al., 2011). Hence, first of all, they need to respond to "emergency calls." Instead of working proactively they end up reacting to students' misfortunes. It can be assumed that their contact with students with AS is mainly based on solving acute problems. They might also have a notion of 
the difficulties these students encounter by having closer contact with parents or legal guardians.

\section{Teachers, principals and SHPs as change agents}

Previous research has suggested that inclusion strategies are found to be most successful when school leaders, SHPs and teachers share common beliefs and make coordinated efforts to work in ways which are consistent with them (see for example Lindqvist \& Nilholm, 2013). Nevertheless, the SR of inclusion exhibited by principals, SHPs and teachers are unquestioningly determined by their respective roles. The components that give the SR its meaning overlap to a certain extent, however it is obvious, nevertheless, that the quality and nature of their collaboration across roles is insufficient to close the gap between the school staff in these schools. This could be because of the nature of present professional development practices or it could be just because of the lack of overlapping perspectives due to the differentiation of roles. Obviously the quality and types of professional development are crucial in conveying the difference between the groups. This lack of shared SRs can be described by SRT. For instance, Jovchelovitch (2007) suggested that when we move between different groups with different conditions and needs, one and the same phenomenon can have different relevance and different demands on shared understanding (Ratinaud \& Lac, 2011). Piaser and Bataille (2011) described this as a professional representation, a subset within an SR if the object and the subjects belong to the same sphere, in this case the pedagogical practice.

By holding onto an environment which is not conducive to co-operation between different levels we miss out on the organization of support to students with special needs, such as students with AS, which has been insinuated in previous research (see for example Heimdahl Mattson \& Malmgren Hansen, 2009). The presence of social and organizational barriers surfaced in our results, which can lead to marginalization and further disable students with invisible disabilities (Lindsay et al., 2013). A way to deal with this might be that principals should consider the extent to which they engage in these practices, with the hope that these barriers can be eliminated in the future.

For change to come about the values that underpin change must also be understood by school leaders in ways that foster active learning activities. Such a process may require ongoing school conversations around what constitutes educational practice conducive to learning for everyone. The power of our SR is the fact that we live in them but are unaware of their existence (Moscovici, 2000). The underlying beliefs about ability and 
propensity to learn is contextual rather than attributed to the individual teacher (Moscovici, 2000), therefore factors such as school norm, the culture or ethos of the school (Dyson et al., 2004; Gibbs, 2007) will likely influence teachers' beliefs.

\section{Students with AS and their inclusion - the objects of the SR investigation}

In this section, the object for SR which is twofold will be analyzed. In Study 1 and 2, the object was students with AS, in Study 3 and 4 the object was inclusion of students with AS.

What happens when we use labels such as AS? This is what Moscovici (2000) called anchoring. We need to anchor new things in something already known to us. Our understanding of the present is based on past experience and ideas at hand, by integrating them into prior experiences and memory (Jovchelovitch, 2007). This is all in accordance with Moscovici's (2000) statement about our history being part of everything we say and do in our daily life without us being aware of its effects on our experience. He argued that our culture and history control our present reality though we are unaware of their power.

Diagnoses are grounded in difficulties and deficiencies, therefore an AS diagnosis might seem very negative. A perception of individual defect has its roots in and is anchored in the medical view of disability which was earlier the dominant model in teacher training and educational provision (Thomas \& Loxley, 2007). While inclusion is the official educational ideology, teachers in their daily interaction with peers and in school activities mainly serve their common sense knowledge. Their SRs carry meaning - often unconsciously in the context they are navigated and enacted hence they can be viewed as a code that guides teachers in their interaction with students (Jovchelovitch, 2007). There is a need to label students which is part of routines and school activity, however, the naming in the school context should be studied as a practice; it is something that the staff does in order to manage their daily chores.

In this dissertation having direct experience of students with AS appeared to be an essential factor in shaping teachers' SR. Teachers without experience may generally rely on media's depiction of individuals with AS. Many of these portrayals have been inaccurate and have contributed to a divergence between general public perception and the reality of AS (Jones \& Harwood, 2009). Even if the differences are small, prior work-related experience seems to shape teachers' SR of students with AS positively, while private experience was associated with less favorable SRs of inclusion. 
The representation supplies teachers with codes for explicitly naming and classifying phenomena in order for teachers to communicate. To know the "object," the student, is to know to what extent the teacher includes the student and what kind of SR of the other establishes a relationship in practice. It seems as though teachers' SR of these students is imbued with scientific knowledge. In spite of the diversity of associations presented by teachers, their understanding leads to the bio-medical approach to AS. Teachers described an array of needs such as support, predictability, quietness, clarity, structure/routine and need for time. Also they stressed the deficiencies in social interaction and rigid and repetitive interest and intellectual profile. This was congruent with the medical diagnosis of DSM- IV (APA, 1994) and its insinuation of behavioral implications seems to close the gap between the descriptions of a student with AS behaviors and the probable causes for the teachers. However, the stimulus phrase was expressed with a denomination from DSM-IV, AS, which might have influenced and triggered associations related to the medical approach. We do not know if the associations would have been different had we not used the term from DSM-IV as the cue.

Previous research has suggested that the placement-oriented definition of inclusion which denotes only the physical placement of students in difficulty is the most common definition of inclusion (e.g., Göransson et al., 2011; Linqvist \& Nilhom, 2013). This was the definition assumed in our collection of empirical data. However, a more nuanced picture was revealed in our results. Teachers frequently mentioned adaptation of the school environment, students as assets and with different potentials which would indicate an individual-oriented definition where the main concern was students with difficulties. This definition also considers the degree of inclusion determined by the situation of the individual student and pedagogical aspects, which we did not explore in this study.

In addition, there were reflections of the definition anchored in the ideal of democratic processes which expressed students' right to participate, inclusion as being important, and inclusion as a basis for equality which partly mirrors the community-oriented definition. The most shared element among the entire school staff was ambient understanding which mirrors a relational SR of inclusion. However, other prerequisites for this definition such as whether the student enjoys school, has good social relationships and attains goals were not explored in our research and hence were beyond the scope of this dissertation. 


\section{Methodological comments}

It is important to point out some methodological limits of the current investigation. First, it is not possible to evaluate representational dynamics, since the design is not longitudinal. Consequently, it is not possible to conclude about the endurance, weakening or reinforcement of its contents. Second, the use of the free association method was helpful in tapping into school staff's system one, in the collection of empirical data; however it decreases the possibilities of a full exploration of the studied concepts in discourse, in this case inclusion. Furthermore, in a strict sense, free associations and prototypical analyses allow only for the formulation of centrality hypothesis, in this investigation the central zone was explored. Other measures, such as the ones based on the questioning, or on the activation of basic cognitive schemes (Guimelli, 1993; Moliner, 1994,) aim at a more exact identification of the central core and its dimensions.

SRT is based on what people see (stimulus) and react upon (response) which is closely tied to the social and cultural context. Therefore, among other things, experiences from day-to-day practice in special education certainly have influenced the process of collecting and dealing with empirical data, categorization and analysis. In this respect, co-occurrence analyses are more flexible in that they are not subject to "researcher bias". When languages are represented using graph theory, the resulting network models reveal how individual semantic phrases are related to one another. They mirror the systems themselves rather than the organizational schema of the researchers who designed for example the macro-categories. This is also true for the prototypical analyses where possible "researcher bias" is reduced because the base for the analyses is the frequency of elements and the ranking performed by the participants themselves.

Because the sample was collected from six municipalities located in the central part of Sweden, the findings of the studies may not be generalized to all teachers. Our aim, however, was to provide in-depth understanding of teachers' SR of including children with AS in mainstream classes.

Overall the differences in the findings are relatively small and consequently caution needs to be exercised in drawing conclusions. However, because the participants in the investigation share the same social and professional context that also shapes their SRs, large differences are precluded. Nevertheless, the structure of the SRs indicated consistent similarities and differences, based on prior experience and the matrix trees underscored how these contributed to form the SR. In addition, because the web-surveys were distributed via school principals, the researcher did not have information about the teachers who did not respond to the survey. Such information could enhance interpretation of the findings. We do not know 
whether the categorization would be maintained if other researchers were to categorize the phrases, however, two teachers and two members of the research team (ACL and PG) examined the words and phrases and put them into categories. When there was a discrepancy in classification, the item was discussed and a fifth person was consulted. In this way, we obtained consensus as to the classification of the words. The use of a medical diagnosis as a stimulus word might have influenced their associations however the term is common knowledge in the educational setting of Sweden.

Inclusion is a culturally specific concept which we assume reduces misunderstandings in the present Swedish context where policies on inclusive education are formulated on the national and municipal levels. Although this is common for the location where our sample was drawn, it may not be typical of all countries.

The sample of principals and SHPs was smaller than that of teachers, but still proportional to the actual ratio of teachers to principals. Nevertheless, our findings were consistent across current roles and were also similar with past research on challenges in educating children with AS.

\section{Future research}

Future research should explore how inclusion is enhanced or inhibited by the design of the classroom and school. The students' voices need to be heard in order to explore how they view the need for adaptation of the school environment and how to attain goals. A further important area for investigation is other variables that might also affect teachers' SR such as systematic support, school culture and changing form and structure of the curriculum under pressures for inclusion. Also, since the Swedish decentralized school system lets municipalities determine the means to achieve the goals for inclusion, the geographic location may be considered as an important variable influencing teachers' SR and attitudes towards inclusive education. Generalizing and expanding findings from this research is needed to test how inclusion might be improved such as whether altering teacher education training might impact on teachers' SRs of students with AS and the actual provision of inclusion. 


\section{Implications and conclusions}

The findings in this dissertation have several important implications for increased attainment of educational targets and reducing school absenteeism among students with AS on the classroom level as well as the structural level.

First, the results suggest that much work is needed before the promise of the inclusion of students diagnosed with AS can be fulfilled. Not only teachers, but also principals and SHPs share SRs indicating that their beliefs and practices do not coincide with the goals of full inclusion. This can also be viewed as full inclusion is not a perfect match for these students. There might be reasons however for more flexible solutions such as being partly included in accordance with the individual-oriented definition.

Second, there is a need for educational programs to better prepare and equip teachers for the challenge of including everyone in the classroom.

Third, the idea of inclusion may need an overall adjustment. Although teachers are generally favorable to students diagnosed with AS, their SRs also indicate some reluctances. These need to be studied further so that they are better understood. However, they also suggest that the idea, however politically correct it is, may lack full contact with the realities of the everyday classroom.

Fourth, however slowly, changes are taking place; recently educated teachers are more apt to adapt the school environment which implies that modern teacher training programs are beneficial for an increased awareness of adapting the school environment.

Fifth, the gender discrepancy implies that there is a need for greater balance between environmental aspects and the individual needs approach.

Sixth, the results indicate that the various professionals need to engage in collaborative professional development. Moreover, the nature of this collaboration needs careful consideration if interventions under the umbrella of inclusion of students with AS are to become a genuine, shared responsibility.

Seventh, our findings were similar to previous studies (see for example Lindqvist \& Nilholm, 2014; Lindsay et al., 2013) which showed that the whole school lacks a common goal of inclusion or what appears to be the status quo where the different staff provides support according to their particular role. In contrast, there is a need for "team building" and an arena for "whole school" conversation. Without a clear common goal the assessment of inclusive practice is not possible. 
In conclusion, even if Swedish school policies have done well to attend to access for students with AS, the results underscore the fact that teachers and school staff are nevertheless still reluctant to being able to fully include these students. School systems consist of an array of taken for granted practices, i.e. routine activities embedded in organizational structures (classrooms with one teacher in charge, etc.) to which not much thought is consciously given, thus not prone to change. We see that systems live side by side despite decades of supporting policies of inclusion. Skidmore (2004), on the other hand, argued that disagreement and conflicts of opinions between different perspectives create an arena for pedagogical development where new ideas rub against the established ones. This is in line with the dynamic property of SRs emphasized by Moscovici (2000) and Voelklein and Howarth (2005) that it is through the contact with conflicting SRs that human beings begin to wonder about their own views and realize what is distinctive about the SRs they hold. It is through such dialogue and reflection that existing representations are adjusted. This is expressed in recent research on inclusion by Hausätter (2014) who describes the conflict between different perspectives in the school arena as an "opening for uncertainty within education that makes the established system more open to change" by pinpointing the flaws of the existing school system to further the need of a fully inclusive educational system.

SRT has guided this research. Theoretically, this thesis draws on tacit knowledge directed by system one, which operates quickly, and automatically and the common sense-making theory to analyze teachers' enactment of inclusion locally. By elucidating the compass behind teachers' interaction, that is, their SRs of students with AS, their common sense knowledge of these students has been explored. Yet, some teachers defined these students' problems as deficits or needs instead of related to a dysfunctional school environment or a combination of the two. Consequently, it was noted that teachers' SRs were not easily changed despite political rhetoric; instead we suggest that some teachers might unconsciously allude to the policies of inclusion while practicing segregation unaware of the tacit or taken for granted knowledge. This is a natural consequence of SRs which reflects how SRs work on a broader social level thus no moral or ethical judgment of teachers is alluded to in this research.

Studies examining the educational provision for learners with AS in Sweden are scarce (Rönnberg et al., 2012). Therefore, it is hoped that this dissertation enhances our understanding of the teacher experience and expectations of having students with AS in an inclusive classroom and that improvements to make schools less exclusive can be proposed. Inclusive education is an ongoing multidimensional and complex process facing challenges at all levels and so awareness of the tacit or taken for granted 
knowledge is a great beginning for a potential change in the content and role of education for all learners.

At the end of the day it is not a question of whether to include or not to include, but rather, as Proust expressed it, it is a question of belonging or not belonging. 


\section{Svensk sammanfattning}

\section{BAKGRUND OCH TEORETISKT RAMVERK}

Målet för en inkluderande skolundervisning är dels att alla elever skall kunna delta i skolans verksamhet och dels att övervinna stereotypa föreställningar som baseras på okunskap. Enligt utbildningspolitiska utlåtanden ska alla elever i möjligaste mån undervisas tillsammans (SNAE, 2007; Skollagen 2010:800). Även internationella riktlinjer och deklarationer som barnkonventionen och Salamankadeklarationen betonar betydelsen av undervisning i gemensamma grupper. Ett flertal undersökningar påvisar dock att inkludering av elever med diagnosen Asperger syndrom (AS) är problematisk i praktiken (SNAE, 2009). Det kan få flera negativa konsekvenser för dessa elever.

Alltfler rapporter visar att skolavhopp och frånvaro utan giltigt skäl under en längre period är ett ökande problem bland elever med AS (SNAE, 2009; Skolinspektionen 2012). Omfattande skolfrånvaro kan leda till allvarliga och betydande negativa konsekvenser för elevens känslomässiga och sociala utveckling och anpassning till samhället (Konstenius \& Schillaci, 2010). Det är inte ovanligt att skolfrånvaron utvecklas under en längre tid utan att den uppmärksammas eller åtgärdas effektivt (SNAE, 2008). Om en elev inte upplever sig delaktig i skolans aktiviteter är risken stor att utanförskap kommer att utvecklas. Problematiken innebär vanligen en stor påfrestning och utmaning för eleverna, föräldrar och skolan (HejlskovElvén, 2009). Inkludering är en central åtgärd för att förhindra dessa problem och därför tycks det vara viktigt att den genomförs i praktiken.

Lärarna spelar en viktig roll för att förverkliga inkludering och deras föreställningar om elever med AS är sannolikt knutna till om, och hur, dessa elever är inkluderade i klassrummet. Därför siktar denna avhandling på att öka kunskap om inkludering av elever med AS genom att undersöka lärares och annan skolpersonals sociala representationer (SR) om inkludering av dessa elever. För att få en bredare syn på inkludering jämförs lärarnas skolhälsoteamens och rektorernas SR om inkludering av elever med AS. Sådana delade idéer i pedagogiska sammanhang har i tidigare forskning tillämpat teorin om sociala representationer (SRT) vilken bygger på antagandet att våra föreställningar ligger till grund för vårt bemötande och handlande. 
Mot denna bakgrund kan SRT vara en lämplig teoretisk modell för att utforska lärares SR, vilka antas vara kompasser som styr lärares förhållningssätt och handlingar (Chaib \& Orfaldi, 1996). Teoribildningens utgångspunkt är att kunskap återskapas i samtal och i samröre med andra gruppmedlemmar, vilket gör att den är användbar i studier av skolpersonals föreställningar och handlingar i den pedagogiska praktiken. Tillsammans utvecklar lärare gemensamma mentala bilder i form av "common sense" som ger innebörd åt fenomen i den pedagogiska verksamheten. Dessa SR fungerar som ett kitt mellan lärare och hjälper dem att kommunicera och orientera sig i den sociala tillvaron (Moscovici, 2000). Eftersom SRT tar hänsyn till historiska och kulturella betingelser, kan den vara till hjälp för att tolka och förstå bakomliggande faktorer som genererar inkludering av dessa elever.

Avhandlingens övergripande syfte är att bidra till ökad kunskap om lärares och övrig skolpersonals sociala representationer om elever med Aspergerdiagnos och en inkluderande skolundervisning för dessa elever. Det övergripande syftet är:

1. Att utforska och analysera lärares och övrig skolpersonals sociala representationer om elever med AS och deras inkludering.

2. Att utröna vilka faktorer som relaterar till positiva attityder till inkludering av elever med AS.

Det övergripande syftet har bruits ner i följande delsyften:

Studie 1. Att belysa lärares sociala representationer av elever med AS.

Studie 2. Att utforska sambandet mellan erfarenhet och lärarnas SR om elever med AS. Att undersöka och att belysa i vilken utsträckning erfarenhet relateras till SR av elever med AS, om arbetsrelaterade erfarenheter av elever med AS påverkar lärarnas SR och om privata upplevelser av AS påverka lärarnas SR av elever med AS .

Studie 3. Att belysa, analysera och jämföra lärares, elevhälsoteams och rektorers SR beträffande inkludering av elever med AS

Studie 4. Att undersöka vilka lärarfaktorer relaterar till en positiv attityd till inkludering av elever med AS. 


\section{MATERIAL OCH METOD}

För att kunna fånga SRs har metoden fria associationer tillämpats i syfte att blottlägga implicita underliggande element. Respondenterna ombeds att utifrån en stimulusfras uttrycka de ord eller fraser de först kommer att tänka på. Metoden riktar sig således mot spontana och mindre kontrollerade utsagor och möjliggör kartläggning av associationens innehåll såväl som dess organisation och inre struktur.

Deltagarna rekryterades via Barn- och utbildningsförvaltningarna i sex kommuner i Mellansverige. Skolpersonal erhöll ett e-postmeddelande innehållande en länk till enkäten med instruktion om att spontant associera till begreppen "elev med Asperger-diagnos" och "inkludering av elever med Asperger-diagnos”. Det fanns utrymme att lämna fem associationer till varje angivet begrepp. Därefter ombads respondenterna att ange huruvida den angivna associationen hade en positiv, neutral eller negativ laddning. Vidare rangordnade respondenten sina associationer i förhållande till de övriga associationerna utifrån hur viktiga de ansåg dem vara och besvarade enkätens övriga frågor. Totalt svarade 170 lärare, 39 skolhälsopersonal och 27 rektorer och 2103 associationer registrerades. För att få en överblick och organisera materialet kategoriserades associationerna i semantiska kategorier.

Undersökningen är indelad i fyra delstudier: Schematisk tablå över studier som ingår i avhandlingen.

\begin{tabular}{|c|c|c|c|}
\hline Studie 1 & Studie 2 & Studie 3 & Studie 4 \\
\hline Fokus: & Fokus: & Fokus: & Fokus: \\
\hline Lärares SR om & Erfarenhetens & Skolpersonals SR om & Lärares attityder \\
\hline $\begin{array}{l}\text { elever med AS- } \\
\text { diagnos }\end{array}$ & $\begin{array}{l}\text { betydelse för } \\
\text { lärares SR om } \\
\text { elever med AS }\end{array}$ & $\begin{array}{l}\text { inkludering av elever } \\
\text { med AS-diagnos }\end{array}$ & $\begin{array}{l}\text { till inkludering } \\
\text { av elever med } \\
\text { AS-diagnos }\end{array}$ \\
\hline Fria associationer & & Fria associationer & \\
\hline $\begin{array}{l}\text { Semantisk } \\
\text { kategorisering }\end{array}$ & $\begin{array}{l}\text { Fria associationer } \\
\text { Semantisk } \\
\text { kategorisering }\end{array}$ & $\begin{array}{l}\text { Semantisk } \\
\text { kategorisering }\end{array}$ & $\begin{array}{l}\text { Associationers } \\
\text { värdeladdning }\end{array}$ \\
\hline $\begin{array}{l}\text { Makro-kategorier } \\
\text { likhetsanalys }\end{array}$ & Likhetsanalys & $\begin{array}{l}\text { Makro-kategorier } \\
\text { Prototypisk analys }\end{array}$ & Självskattning \\
\hline Lärare $\mathrm{N}=170$ & $\begin{array}{l}\text { Relative Risk } \\
\text { Increase } \\
\text { Lärare N=153 }\end{array}$ & $\begin{array}{l}\text { Lärare, rektorer, } \\
\text { skolhälsoteam } \\
\mathrm{N}=223\end{array}$ & Lärare N= 163 \\
\hline
\end{tabular}


Den första studien utforskade lärarnas SR om elever med AS och undersökte på vilket sätt undervisningsnivå, lärarens kön och lärarutbildning relateras till deras SR. Resultaten visar att lärarna har en förhållandevis gemensam social representation av elever med AS. De centrala elementen i lärarnas SR relaterar till dysfunktion inom individen som till stor del motsvarar Wings triad såsom brister i social interaktion, intellektuell profil och specialintresse (Wing, 1981). Det medicinska förhållningssättet, som söker kroppsliga förklaringar till individens svårigheter, dominerar speciellt lärare med tidigare lärarutbildning. Bland lärare med senare lärarutbildning finns mindre fokus på funktionshinder men mer på anpassning av skolmiljön och undervisningsmetoder.

En tredjedel av associationerna relateras till skolmiljön och lärandesituationen. Som framgår av tidigare forskning finns en uppenbar skillnad mellan könen; manliga lärare är mer benägna att anpassa skolmiljön till elever med AS medan kvinnliga lärare är mer fokuserade på behov och elevens välbefinnande. Lärares fokus på funktionshinder minskar med högre stadium medan anpassning av skolmiljön ökar med högre stadium.

Den andra studien syftade till att utöka förståelse av resultatet i första studien genom att utröna den roll erfarenheten spelar i lärares representationer. Resultatet indikerar att erfarenheter från arbetslivet modifierar och genererar en mer positiv SR hos lärare i jämförelse med de som saknar en sådan erfarenhet. Samtidigt är lärare med erfarenheter från privatlivet mindre positiva än de som enbart har arbetsrelaterad erfarenhet.

Den tredje studien jämförde SR hos lärare, elevhälsoteam och rektorer med fokus på inkludering av elever med AS-diagnos. Resultaten tyder på att lärare är mer positiva till inkludering än andra grupper av skolpersonal. Rektorer fokuserar mer på miljöaspekter medan skolhälsoteamet betonar elevernas behov, deras olika potentialer och vikten av anpassning av skolmiljön. Resultaten indikerar att det finns en klyfta mellan organisationsnivån, klassrumsnivån och individnivån för att främja inkludering av elever med ASdiagnos.

Den fjärde studien undersökte lärares attityder till inkludering av elever med AS-diagnos och vilka faktorer som relaterar till positiva attityder till inkludering av dessa elever. I enlighet med tidigare forskning visar studien att lärarnas inställning till inkludering av elever med AS är mestadels positiv och har ett samband med deras attityder till elever med AS. Lärare på lägre stadier är mindre positiva till inkludering av elever med AS än lärare på högstadiet och gymnasieskolan. Positiva attityder till inkludering av elever med AS relaterar till lärarnas kunskap om undervisning av elever med AS och deras attityd till individen. 


\section{DISKUSSION OCH SAMMANFATTNING}

Resultaten pekar på att full inkludering av elever med AS är ett strävandemål som långt ifrån är uppnått. Det kan tolkas som att lärares SR om inkludering av elever med AS inte stämmer med dessa elevers behov vilket framgår av olika utsagor från lärare med erfarenhet från privatliv, rektorer och skolhälsoteam. Det kan tolkas som att det finnas anledning till mer flexibla lösningar för just dessa elever. Det kan även tolkas som att det finns ett stort behov av utbildning för att bättre rusta lärare och övrig skolpersonal för den utmaning inkludering innebär. Den ena tolkningen utesluter inte den andra. Trots att skillnaderna är små är lärare med praktisk erfarenhet av undervisning av elever med AS mer positiva än lärare utan sådan erfarenhet.

Inom Social representationsteori lyfts frågan i vilken utsträckning SR är delade. Det är viktigt att understryka att SR inte är liktydigt med konsensus. Det finns motstridiga föreställningar inom gruppen lärare, men som grupp har de gemensamma begrepp och referensramar. Det möjliggör kommunikation oavsett om idéerna delas av alla lärare. SR präglas av olika idéer och perspektiv som bryts mot varandra. Specialpedagogikens roll stöts och blöts mot en förändrad syn på segregerade lösningar utifrån en inkluderande pedagogisk filosofi. Den historiska dimensionen av SR påverkar hur lärare tänker och handlar i nutid.

Utifrån skillnader i professionernas sociala representationer framgår att det finns ett behov av att överbrygga klyftan mellan individnivå, klassrumsnivå och organisationsnivå. Det saknas ett gemensamt mål för alla aktörer inom skolan lokalt (kommunen). Utan ett tydligt uppsatt mål blir inte inkludering ett gemensamt ansvar och kan inte heller utvärderas i termer av måluppfyllelse. 


\section{References}

Abikoff, H., Jensen, P., \& Arnold, E. (2002). Observed classroom behavior of children with ADHD: Relationship to gender and comorbidity. Journal of Abnormal Child Psychology, 30(4), 349-359.

Abric, J. (2001). A structural approach to social representations. Representations of the social. In K. Deaux, \& G. Philogene (Eds.), Oxford: Blackwell.

Abric, J. (2003). Méthodes d'étude des représentations sociales. Ramonville Saint-Agne: Eres.

Adamson, A., O'Hare, A., \& Graham, C. (2006). Impairments in sensory modulation in children with autisitc spectrum disorder. The British Journal of Occupational Therapy, 69(8), 357-368.

Ainscow, M., Booth, T., \& Dyson, A. (2006). Improving schools, developing inclusion. Abingdon: Routledge.

Ainscow, M., \& Miles, S. (2008). "Making education for all inclusive: Where next?". Prospects, 38(1), 15-34.

Ainscow, M., \& Sandhill, A. (2010). Developing inclusive education systems: The role of organizaitonal cultures and leadership. International Journal of Inclusive Education, 14(4), 401-416.

Akin, I., \& Neumann, C. (2013). Identifying proactive collaboration strategies for teacher readiness for marginalized students. Journal of College Teaching \& Learning, 10(4), 235-244.

Alexander, R. (2004) Still no pedagogy? Principle, pragmatism and compliance in primary education. Cambridge Journal of Education, 34(1), 7-33.

Allen, K., \& Cowdery, G. (2005). The exceptional child: Inclusion in early childhood education. Clifton Park, NY: Thomson Delmar Learning.

Almvik, L. (2010). Autism- och aspergerförbundets undersökning om skolfrånvaro. An exploration of absenteeism by the Swedish association for autism and asperger syndrome. Stockholm: The Swedish Association for Autism and Asperger Syndrome.

Alves-Mazzotti, A. (2011). Being a school teacher in Brazil. In M. Chaib, B. Danermark \& S. Selander (Eds.), Education, professionalization and social representations: On the transformation of social knowledge (pp. 136-146). New York: Routledge. 
Andersén, A. (2011). Ett särskilt perspektiv på högre studier? folkhögskoledeltagares sociala representationer om högskola och universitet. Jönköping University: School of Education and Communication.

APA (American Psychiatric Association). (1994). Diagnostic and statistical manual of mental disorders. DSM-IV (4th edition) Washington. DC: APA.

APA (American Psychiatric Association). (2013). Diagnositic and statistical manual of mental disorders (5th edition). Washingtion DC: APA

Armstrong, D. (2013). Educator perceptions of children who present with social, emotional and behavioural difficulties: A literature review with implications for recent educational policy in England and internationally. International Journal of Inclusive Education, doi:10.1080/13603116.2013.823245

Armstrong, D., \& Hallett, F. (2012). Private knowledge, public face: Conceptions of children with SEBD by teachers in the UK - A case study. Educational and Child Psychology, 29(4), 77-87.

Arnesen, A., \& Lundahl, L. (2006). Still social and democratic? inclusive education policies in the Nordic welfare states, Scandinavian. Journal of Educational Research, 50(3), 285-300.

Arthur-Kelly, M., Sutherland, D., Lyons, G., Macfarlane, S., \& Foreman, P. (2013). Reflections on enhancing pre-service teacher education programmes to support inclusion: Perspectives from New Zealand and Australia. European Journal of Special Needs Education, 28(2), 217233.

Artiles, A., Kozleski, E., Dorn, S., \& Christensen, S. (2006). Learning in inclusive education research: Re-mediating theory and methods with a transformative agenda. Review of Research in Education, 30, 65-108.

Ashburner, J., Ziviani, J., \& Rodger, S. (2010). Surviving in the mainstream: Capacity of children with autism spectrum disorder to perform academically and regulate their emotions and behavior at school. Research in Autism Spectrum Disorders, 4(1), 18-27.

Ashburner, J., Ziviani, J., \& Rodger, S. (2008). Sensory processing and classroom emotional, behavioral and educational outcomes in children with autism spectrum disorder. American Journal of Occupational Therapy, 62, 564-573.

Attwood, T. (2007). The complete guide to Asperger's syndrome. London: Jessica Kingsley Publishers.

Avramidis, E., Bayliss, P., \& Burden, R. (2000). A survey into mainstream teachers' attitude towards the inclusion of children with special eductional needs in the ordinary school in one local education authority. Educational Psychology, 20(2) 191-211. 
Avramidis, E., \& Norwich, B. (2002). Teachers' attitudes towards integration / inclusion: A review of the literature. European Journal of Special Needs Education, 17(2), 129-147. doi:10.1080/08856250210129056

Bain, S., Brown, K., \& Jordan, K. (2009). Teacher candidates' accuracy of beliefs regarding childhood interventions. The Teacher Educator, 44, 71-89.

Baker, A., Lane, A., Angley, M., \& Young, R. (2008). The relationship between sensory processing patterns and behavioral responsiveness in autistic disorder: A pilot study. Journal of Autism and Developmental Disorders, 28, 867-875.

Bales, M., \& Johnson, S. (2006). Graph theoretic modeling of large-scale semantic networks. Journal of Biomedical Informatics, 39, 451-464.

Barbier, J. M. (2011). Social representations and cultures of action. In M. Chaib, B. Danermark \& S. Selander (Eds.), Education, professionalization and social representations: On the transformation of social knowledge. (pp. 86-105). New York: Routledge.

Baron-Cohen, S., Scott, F., Allison, C., William, J., Bolton, P., Mattews, F., \& Brayne, C. (2009). Prevalence of autism-spectrum conditions: UK school-based population study. The British Journal of Psychiatry, (6), 500-509. doi:10.1192/bjp.bp.108.059345

Batten, A. (2005). Inclusion and the autism spectrum. Improving Schools, 8(1), 93-96. doi:10.1177/1365480205049341

Bauer, M., \& Gaskell, G. (2008). Social representations theory: A progressive research programme for social psychology. Journal for the Theory of Social Behaviour, 38(4), 335-353.

Bentley, J. K. (2008). Lessons from the 1\%: Children with labels of severe disabilities and their peers as architects of inclusive education. International Journal of Inclusive Education, 12(5-6), 543-561.

Berger, P., \& Luckmann, T. (1966). The social construction of reality: A treatise in the sociology of knowledge. London: Penguin Books.

Bergmo Prvulovic, I. (2015). Social representations of career and career guidance in the changing world of working life. Jönköping University: School of Education and Communication.

Berhanu, G. (2011). Inclusive education in Sweden: Responses, challenges, and prospects. International Journal of Special Education, 26(2), 128148.

Billing, M. (1993). Studying the thinking society: Social representations, rhetoric, and attitudes in empirical approaches to social representations. In G. M. Breakwell, \& D. V. Canter (Eds.), Empirical approaches to social representations. Oxford: Oxford University Press. 
Bodet, G., Meurgey, B., \& Lacassagne, M. (2009). Brand social representations: Strategic perspectives for a fitness club. International Journal of Sport Management and Marketing, 5, 369-383.

Bourdieu, P. (1984). Distinction. London: Routledge and Kegan Paul. Boyle, C., Topping, K., \& Jindal-Snape, D. (2013). Teachers' attitudes towards inclusion in high schools. Teachers and Teaching: Theory and Practice, 19(5), 527-542.

Breeman, L., Wubbels, T., van Lier, P., Verhulst, F., van der Ende, J., Maras, A., .. . Tick, N. (2015). Teacher characteristics, social classroom relationships and children's social, emotional, and behavioral classrooms adjustment in special education. Journal of School Psychology, 53(1), 87-103. doi:10.1016/j.jsp.2014.11.005

Campbell, C. (2002). Developing inclusive schooling: Perspectives, policies and practices. London: Institute of Education, University of London.

Carroll, A., Forlin, C., \& Jobling, A. (2003). The impact of teacher training in special education on the attitudes of Australian pre-service general educators towards people with disabilities. Teacher Education Quarterly, 30, 65-79.

Chaib, M.,\& Orfali, B. (1996). Sociala representationer: Om vardagsvetandets sociala fundament. Göteborg: Daidalos.

Chaib, M., \& Chaib, J. (2011). Teacher students' social representations of how adults learn. In M. Chaib, B. Danermark \& S. Selander (Eds.), Education, professionalization and social representations: On the transformation of social knowledge (pp. 123-133)

Chiang, H., Cheung, Y., Hickson, L., Ziang, R., \& Tsai, L. (2012). Predictive factors of participation in postsecondary education for high school leavers with autism. Journal of Autism and Developmental Disorders, 42, 685-696. doi:10.1007/s10803-011-1297-7

Coles, E., Slavec, J., Bernstein, M., \& Baroni, E. (2012). Exploring the gender gap in referrals for children with ADHD and other disruptive behavior disorders. Journal of Attention Disorders, 16(2), 101-108.

Connor, M. (1999). Asperger children on the autistic spectrum: Guidelines for mainstream practice. Support for Learning, 14(2), 80-86.

Cooper, P. (2011). Teacher strategies for effective intervention with students presenting social emotional and behavioural difficulties: An international review. European Journal of Special Needs Education, 26(1), 71-86.

Coronges, K., Stacy, A., \& Valente, T. (2007). Structural comparison of cognitive associative networks in two populations. Journal of Applied Social Psychology, 37, 2097-2129.

Cowne, E. (2005). What do special educational needs coordinators think they do? Support for Learning, 20(2), 61-68. 
Cremin, H., \& Thomas, G. (2005). Maintaining underclasses via contrastive judgement: Can inclusion ever happen? British Journal of Educational Studies, 53(4), 431-446.

David, R., \& Kuyini, A. B. (2012). Social inclusion: Teachers as facilitators in peer acceptance of students with disabilities in regular classrooms in Tamil Nadu, India. International Journal of Special Education, 27(2), 157-168.

Demetriou, H., Wilson, E., \& Winterbottom, M. (2009). The role of emotions in teaching: Are there differences between male and female newly qualified teachers' approaches to teaching? Educational Studies, 35(4), 449-473.

Doise, W. (1995). Förankring vid studiet av sociala representationer. In M. Chaib, \& B. Orfaldi (Eds.), Sociala representationer: Om vardagsvetandets sociala fundament (pp. 83-95). Göteborg: Daidalos.

Doise, W. (1992). L'ancrage dans les études sur les reprédentations sociales. Bulletin De Psychologie, 45, 405.

Durkheim, E. (1898/1974). In Durkheim E. (Ed.), Individual and collective representations in sociology and philosophy. New York: Free Press.

Dworzynski, K., Ronald, A., Bolton, P., \& Happe, F. (2012). How different are girls and boys above and below the diagnostic threshold for autism spectrum disorders? Journal of American Child \& Adolescent Psychiatry, 51(8), 788-797.

Dyson, A. (2001). Special needs in the twenty-first century: Where we've been and where we're going. British Journal of Special Education, 28, 24-28.

Dyson, A., Farrell, P., Polat, F., Hutcheson, G., \& Gallannaugh, F. (2004). Inclusion and pupil achievement (Research Report No. RR578). London: Department for Education and Skills.

Ehlers, S., \& Gillberg, C. (1993).The epidemiology of Asperger syndrome. A total population study. J Child Psychol Psych, 34, 1327-1350.

Emam, M., \& Farrell, P. (2009). Tensions experienced by teachers and their views of support for pupils with autism spectrum disorders in mainstream schools. European Journal of Special Needs Education, 24(4), 407-422.

Esbensen, A., Seltzer, M., Lam, K., \& Bodfish, J. (2009). Age-related differences in restricted repetitive behaviors in autism spectrum disorder. Journal of Autism and Developmental Disabilities, 39(1), 57-66.

Falkmer, M. (2013). "From eye to us- prerequisites for and levels of participation in mainstream school of persons with autism spectrum conditions. Jönköping: School of Education and Communication, Jönköping University. 
Farr, R. (1993). In Breakwell G. M., Canter D. V. (Eds.), Theory and method in the study of social representations in empirical approaches to social representations. Oxford: Clarendon Press.

Farrell, P., Dyson, A., Hutcheson, G., \& Gallannaugh, F. (2007). Inclusion and achievement in mainstream schools. European Journal of Special Needs Education, 22(2), 131-145.

Fein, D., Barton, M., Eigsti, I., Kelley, E., Naigles, L., \& Schultz, R. (2013). Optimal outcome in individuals with a history of autism. Journal of Child Psychology and Psychiatry, 54(2), 195-205.

Ferreira, A., Corso, G., Piuvezam, G., \& Alves, M. (2006). A scale-free network of evoked words. Brazilian Journal of Physics, 36(2a), 755758.

Flament, C. (1994). L'analyse de similitude: Une technique pour les représentations sociales/ similarity analysis: A technique for researches in social representations. Current Psychology of Cognition, 1, 375-395.

Florian, L. (2007). In Florian L. (Ed.), Reimagining special education [The Sage Handbook of Special Education]. London: Sage Publications.

Florian, L., \& Black-Hawkins, K. (2011). Exploring inclusive pedagogy. British Educational Research Journal, 37(5), 813-828.

Florian, L., \& Spratt, J. (2013). Enacting inclusion: A framework for interrogating inclusive practice. European Journal of Special Needs Education, 28(2), 119-135.

Florian, L., \& Rouse, M. (2001). Inclusive practices in English secondary schools: Lessons learned. Cambridge Journal of Education, 31(3)

Forlin, C., Loreman, T., Sharma, U., \& Earle, C. (2009). Demographic differences in changing pre-service teachers' attitudes, sentiments and concerns about inclusive education. International Journal of Inclusive Education, 13(2), 195-209.

Forlin, C., \& Chambers, D. (2011). Teacher preparation for inclusive education: Increasing knowledge but raising concerns. Asia-Pacific Journal of Teacher Education, 39(1), 17-32.

Frederickson, A., Jones, A., \& Lang, J. (2010). Inclusive provision options for pupils on the autistic spectrum. Journal of Research in Special Educational Needs, 10(2), 63-73.

Frith, U., \& Happe, F. (1994). Autism: Beyond "theory of mind". Cognition, 50, 115-132.

Gerhardt, P., \& Lainer, I. (2010). Addressing the needs of adolescents and adults with autism: A crisis on the horizon. Journal of Contemporary Psychotherapy, 41, 37-45.

Gibbs, S. (2007). Teachers' perceptions of efficacy: Beliefs that may support inclusion or segregation. Educational and Child Psychology, 24, 47-53. 
Gillberg, C., Cererlund, M., Lamberg, K., \& Zeijlon, l. (2006). Brief report: "the autism epidemic": The registered prevalence in autism in a Swedish urban area. Journal of Autism and Developmental Disorders, 35(2), 429435.

Gilmore, L., Campbell, J., \& Cuskelly, M. (2003). Developmental expectations, personality stereotypes, and attitudes towards inclusive education: Community and teacher views of Down syndrome. International Journal of Disability Development and Education, 50(1), 65-76.

Göransson, K. (2006). Pedagogical traditions and conditions for inclusive education. Scandinavian Journal of Disability Research, 8, 67-74.

Göransson, K., Nilholm, C., \& Karlsson, K. (2011). Inclusive education in Sweden? A critical analysis. International Journal of Inclusive Education, 15(5), 541-555.

Graham, L. (2006). Caught in the net: A foucaultian interrogation of the incidental effects of limited notions of inclusion. International Journal of Inclusive Education, 10(1), 3-25.

Granbom, I. (2011). "Vi har nästan blivit för bra". Lärares sociala representationer av förskolan som pedagogisk praktik. Jönköpings University: Jönköping: School of Education and Communication.

Greenwald, A. G., Poehlman, T., Uhlman, E., \& Banaji, M. R. (2009). Understanding and using the implicit association test:III. meta-analysis of predictive validity. Journal of Personality and Social Psychology, 97, 17-41.

Grenier, G. (2010). Moving to inclusion: A socio-cultural analysis. International Journal of Inclusive Education, 14(4), 387-400.

Guimelli, C. (1993). Concerning the structure of social representations. Papers on Social Representations, 2(2), 85-92.

Haase, M. (2008). 'I don't do the mothering role that lots of female teachers do': Male teachers, gender, power and social organization. British Journal of Sociology of Education, 29(6)

Halinen, I., \& Järvinen, R. (2008). Towards inclusive education: The case of Finland. Prospects, 38(1), 77-97. doi:10.1007/s11125-008-9061-2

Happé, F. (1993). Communicative competence and theory of mind in autism: A test of relevance theory. Cognition, 48, 101-119.

Harma, K., Gombert, A., \& Rousseya, J. (2013). Impact of mainstreaming and disability visability on social representation of disability and otherness held by junior high school pupils. International Journal of Disability Development and Education, 60(4), 312-331.

Hattie, J. A. C. (Ed.). (2012). Visible learning for teachers: Maximizing impact on learning. New York: Routledge. 
Haug, P. (1998). Pedagogiskt dilemma: Specialundervisning. Stockholm: Liber.

Haug, P. (2014). Empirical shortcomings? A comment on Kerstin Göransson and Claes Nilholm: Conceptual diversities and empirical shortcomings a critical analysis of research in inclusive education. European Journal of Special Needs Education, 29(3), 283-285.

Hausstätter, R. (2014). In support for unfinished inclusion. Scandinavian Journal of Educational Research, 58(4), 424-434.

Hausstätter, R., \& Takala, M. (2008). The core of special teacher education: A comparison of Finland and Norway. European Journal of Special Needs Education, 23(2), 121-134.

Heimdahl-Mattson, E., \& Malmgren-Hansen, A. (2009). Inclusive and exclusive education in Sweden: Principals' opinions and experiences. European Journal of Special Needs Education, 24(4), 465-472.

Hein, S., Grumm, M., \& Fingerle, M. (2011). Is contact with people with disabilities a guarantee for positive implicit and explicit attitudes? European Journal of Special Needs Education, 26(4), 509-522.

Hejlskov Elvén, B. (2009). Problemskapande beteende vid utvecklingsmässiga funktionshinder. Lund: studentlitteratur.

Hellberg, K. (2007). Elever på ett anpassat individuellt gymnasieprogram: Skolvardag och vändpunkter [students' experiences and turning points in a special adapted high school program]. Linköping: Linköpings Universitet.

Hetzler, A., Melén, D., \& Bjerstedt, D. (2005). Sjuksverige: Försäkringskassan, rehabilitering och utslagningen från arbetsmarknaden. Stockholm: Symposion.

Hjörne, E., \& Säljö, R. (2008). Att platsa i en skola för alla. elevhälsa och förhandling om normalitet i den svenska skolan . Stockholm: Norstedts Akademiska Förlag.

Hornstra, L., Bergh, E., Bakker, J., Denessen, L., Bergh, L., \& Voeten, M. (2010). Teacher attitudes toward dyslexia: Effects on teachers' expectations and the academic achievement of students with dyslexia. Journal of Learning Disabilities, 43(6), 515-529.

Howarth, C. (2004). Re-presentation and resistance in the context of school exclusion: Reasons to be critical. Journal of Community \& Applied Social Psychology, 14(5), 356-377.

Howarth, C. (2006). A social representation is not a quiet thing: Exploring the critical potential of social representations theory. British Journal of Social Psychology, 45(1), 65-86.

Humphrey, N. (2008). Including pupils with autistic spectrum disorders in mainstream schools. Support for Learning, 23(1), 41-47. doi:10.1111/j.1467-9604.2007.00367.x 
Humphrey, N., \& Lewis, S. (2008). 'Make me normal': The views and experiences of pupils on the autistic spectrum in mainstream secondary schools. Autism : The International Journal of Research and Practice, 12(1), 23-46. doi:10.1177/1362361307085267

Huws, J., \& Jones, R. (2011). Missing voices: Representations of autism in British newspapers, 1999-2008. British Journal of Learning Disabilities, 39(2), 98-104.

Isaksson, J., Lindqvist, R., \& Bergström, E. (2007). School problems or individual shortcomings? A study of individual educational plans in Sweden. European Journal of Special Needs Education, 22(1), 75-91.

Jaspars, J., \& Fraser, C. (1984). Attitudes and social represenations. In R. M. Farr, \& S. Moscovici (Eds.), Social representations (pp. 101-123). Cambridge: Cambridge University Press.

Jerlinder, K., Danermark, B., \& Gill, P. (2010). Swedish primary-school teachers' attitudes to inclusion- the case of PE and pupils with physical disabilities. European Journal of Special Needs Education, 25(1), 45-57.

Jodelet, D. (1995). Sociala representationer: Ett forskningsområde under utveckling. In M. Chaib, \& B. Orfali (Eds.), Sociala representationer: Om vardagsvetandets sociala fundament (pp. 27-56). Göteborg: Daidalos.

Jodelet, D. (2008). Social representations: The beautiful invention. Journal for the Theory of Social Behaviour, 38(4), 411-430.

Jones, S., \& Harwood, V. (2009). Representations of autism in Australian print media. Disability \& Society, 24(1), 5-18.

Jordan, A., Schwartz, E., \& McGhie-Richmond, D. (2009). Preparing teachers for inclusive classrooms. Teaching and Teacher Education, 25(4), 535-542.

Jordan, R. (2008). Autistic spectrum disorders: A challenge and a model for inclusion in education. British Journal of Special Education, 35(1), 1115.

Jordan, R. (2005). Managing autism and asperger's syndrome in current educational provision. Pediatric Rehabilitation, 8(2), 104-112.

Jovchelovitch, S. (2007). Knowledge in context: Representations, community and Culture. London: Routledge.

Kahneman, D. (2011). Thinking, fast and slow. London, England: Penguin books.

Kahneman, D., \& Tversky, A. (1984). Choices, values and frames. American Psychologist, 34

Kogan, M., Blumberg, S., \& Schieve, L. (2009). Prevalence of parentreported diagnosis of autism spectrum disorder among children in the US. Pediatrics, 124(5), 1395-1403. 
Konstenius, V., \& Schillaci, M. (2010). Skolfrånvaro - KBT-baserat kartläggnings- och åtgärdsarbete. Lund: Studentlitteratur.

Kugelmass, J., Ainscow, M. (2004). Leadership for inclusion: A comparison of international practices. Journal of Research in Special Educational Needs, 4(3), 133-141.

Lahlou, S., \& Abric, J. (2011). What are the "elements" of a representation? Papers on Social Representations, 20(20), 1-20.

Lake, J., Perry, A., \& Lunsky, Y. (2014). Mental health services for individuals with high functioning autism spectrum disorder. Autism Research and Treatment, 2014(1), 1-9.

Larsson Abbad, G. (2007). "Asperger'n det är jag": En intervjustudie om att leva med asperger syndrom ["aspie, that's me": Personal experiences of living with asperger syndrome]. Linköping: Linköpings universitiet.

Lindqvist, G. (2013). SENCOs: Vanguards or in vain? Journal of Research in Special Educational Needs, 13(3), 198-207.

Lindqvist, G., \& Nilholm, C. (2013). Making schools inclusive? Educational leaders' view on how to work with children in need of special support. International Journal of Inclusive Education, 17(1), 95-110.

Lindqvist, G., \& Nilholm, C. (2014). Promoting inclusion? "Inclusive" and effective head teachers' descriptions of their work. European Journal of Special Needs Education, 29(1), 74-90.

Lindqvist, G., Nilholm, C., Almqvist, L., \& Wetso, G. (2011). Different agendas? The views of different occupational groups on special needs education. European Journal of Special Needs Education, 26(2), 143157.

Lindsay, S., Proulx, M., Thomson, N., \& Scott, F. (2013). Educators' challenges of including children in mainstream classrooms. International Journal of Disability Development and Education, 60(4), 347-362.

Loreman, T., Sharma, U., Earle, C., \& Forlin, C. (2007). The development of an instument for measuring pre-service teachers' sentiments, attitudes and concerns about inclusive education. International Journal of Special Education, 22(2), 150-159.

Mäkiniemi, J., Pirttilä-Backman, A., \& Pieri, M. (2011). Ethical and unethical food. social representations among Finnish, Danish and Italian students. Appetite, 56, 495-502.

Marková, I. (2003). Dialogicality and social representations: The dynamics of mind. Cambridge: Cambridge Univeristy Press.

Mavropoulou, S., \& Avramidis, E. (2012). Befrienders to persons in the autistic spectrum in Greece: What support do they offer and what challenges they face? European Journal of Special Needs Education, 27(3), 337-353. 
McGregor, E., \& Campbell, E. (2001). The attitudes of teachers in Scotland to the integration of children with autism into mainstream schools. Autism : The International Journal of Research and Practice, 5(2), 189207. doi:10.1177/1362361301005002008

McIntyre, L. L. (1990). Teacher standards and gender: Factors in special education referral? The Journal of Educational Research, 83(3), 166172.

McKinlay, A., \& Potter, J. (1987). Social representations: A conceptual critique. Journal for the Theory of Social Behaviour, 17(4), 471-487.

McLaren, S. J. (2013). Is inclusive education right for every child? An account of the parent of a child with high and complex needs due to autism spectrum disorder. Kairaranga,14(2), 26-34.

Molinari, L., \& Emiliani, F. (1996). More on the structure of social representations: Central core and social dynamics. Papers on Social Representations, 5(41), 49.

Moliner, P. (1994). Les méthodes de repérage et d'identification du noyau des représentaions sociales. In C. Guimelli (Ed.), Structures et transformations des représentations sociales (pp. 199-232) Lausanne: Delachaux et Niestlé.

Moloney, G. (2010). Acknowledging Gerald. Articulating social representations and identity through process \& content: The resettlement of refugee in regional Australia. Papers on Social Representations, 19, 15.01-15.16.

Moores-Abdool, W. (2010). Included students with autism and access to general curriculum: What is being provided? Issues in Teacher Education, 19(2), 153-169.

Moscovici, S. (2000). Social representations: Explorations in social psychology. . Cambridge: Polity Press.

Moscovici, S. (1984). The phenomenon of social representations. In R. Farr, \& S. Moscovici (Eds.), Social representations (pp. 3-77). Cambridge: Cambridge University Press.

Myles, B. (2003). Behavioral forms of stress management for individuals with Asperger syndrome. Child Adolescence Psychiatry, 12(1), 123-41.

Newman, L. (2007). Secondary school experiences of students with autism. Menlo Park, CA: SRI International.

Nilholm, C. (2007). Perspektiv på specialpedagogik [perspectives on special education]. Lund: Studentlitteratur.

Nilholm, C. (2008). Gör politiken skillnad? exemplet "elever i behov av särskilt stöd". Utbildning \& Demokrati, 17(1), 109-123.

Nilholm, C., \& Göransson, K. (2014). Inkluderande undervisning - vad kan man lära sig av forskningen? [Inclusive education - what can you learn 
from the research? (forsknings- och utvecklingsrapport No.

3).Specialpedagogiska skolmyndigheten.

Nilholm, C. (2006). Special education, inclusion and democracy. European Journal of Special Needs Education, 21(4), 431-445.

Nilholm, C., Almqvist, L., Göransson, K., \& Lindqvist, G. (2013). Is it possible to get away from disability-based classifications in education? An empirical investigation of the Swedish system. Scandinavian Journal of Disability Research, 15(4), 379-391.

Nordahl, T., Hausstätter,R. (2009). Spesialundervisningens forutsetninger, innsatser og resultater. situasjonen til elever med scrlige behov under kunnskapsløftet [special education under the knowledge promotion reform]. Hamar: Høgskolen i Hedmark/ Utdanningsdirektoratet.

Norwich, B. (2008). Difference, inclusion and disabilty. International perspective and future directions. Oxford: Routledge.

Osborne, L. A., \& Reed, P. (2011). School factors associated with mainstream progress in secondary education for included pupils with autism spectrum disorders. Research in Autism Spectrum Disorders, 5(3), 1253-1263. doi:10.1016/j.rasd.2011.01.016

Parales Quenza, C. J. (2005). On the structural approach to social representations. Theory \& Psychology, 15(1), 77-100.

Parsons, S., Guldberg, A., MacLeod, A., Jones, G., Prunty, A., \& Balfe, T. (2011). International review of the evidence on best practice in educational provision for children on the autism spectrum. European Journal of Special Needs Education, 26(1), 47-63.

Parsons, S., \& Lewis, A. (2010). The home-education of children with special needs or disabilities in the UK: Views of parents from an online survey. International Journal of Inclusive Education, 14(1), 1-34. doi:10.1080/13603110802504135

Pennington, B., \& Ozonoff, S. (1996). Executive functions and developmental psychopathology. Psychology and Psychiatry, 37, 10811105.

Persson, B. (2008). On other people's terms: Schools' encounters with disabled students. European Journal of Special Needs Education, 23(4), 337-347.

Persson, B. (2003). Exclusive and inclusive discourses in special education research and policy in Sweden. International Journal of Inclusive Education, 7(3), 271-280.

Piaget, J. (1964). Cognitive development in children. Journal of Research in Science Teaching, 2(3), 176-186. 
Piaser, A., \& Bataille, M. (2011). Of contextualized use of "social" and "professional". In M. Chaib, B. Danermark \& S. Selander (Eds.), Education, professionalization and social representations. On the transformation of social knowledge (pp. 44-54)

Pijl, S., \& Van den Bos, K. (2001). Redesigning regular education support in the Netherlands. European Journal of Special Needs Education, 16(2), 111-120.

Pisula, E., \& Lukowska, E. (2011). Perception of social relationships with classmates and social support in adolescents with Asperger syndrome attending mainstream schools in Poland. School Psychology International, 33(2), 185-206. doi:10.1177/0143034311415784

Pyle, N., \& Wexler, J. (2012). Preventing students with disabilities from dropping out. Intervention in School and Clinic, 47(5), 283-289. doi:10.1177/1053451211430118

Ratinaud, P., \& Lac, M. (2011). Understanding professionalization as a representational process. In M. Chaib, B. Danermark \& S. Selander (Eds.), Education, professionalization and social representations: On the transformation of social knowledge (pp. 55-67). New York: Routledge.

Ratinaud, R. (2009). IRaMuTeQ: Interface de R pour les analyses multidimentionnelles de textes et de questionnnaires (online) doi:available at http://www.iramuteq.org

Ravet, J. (2011). Inclusive/Exclusive? Contradictory perspectives on autism and inclusion: The case for an integrative position. International Journal of Inclusive Education, 15(6), 667-682. doi:10.1080/13603110903294347

Riddell, S. (2009). Social justice, equality and inclusion in Scottish education. Discourse: Studies in the Cultural Politics of Education, 30(3), 283-296.

Robertson, K., Chamberlain, B., \& Kasari, C. (2003). General education teachers' relationships with included students with autism. Journal of Autism and Developmental Disorders, 33(2), 123-131.

Rönnberg, J., Classon, B., Danermark, B., \& Karlsson, T. (2012). Forskning om funktionsnedsättning och funktionshinder 2002-2010: Kartläggning, analys och förslag. Institutet för handikappvetenskap, IHV, Linköpings och Örebro universitet: Forskningsrådet för arbetsliv och socialvetenskap.

Rouse, M. (2009). Developing inclusive practice: A role for teachers and teacher education? Education in the North, 16, 6-11.

SALAR (Swedish Association of Local Authorities and Regions). (2010). Official statistics from the Swedish association of local authorities and 
regions (SALAR) Nov 2010 (personal letter 2012-01-26). Unpublished manuscript.

School Inspectorate. (2012). "Inte enligt mallen” om skolsituationen för elever i grundskolan med diagnos inom autismspektrumtillstånd. (kvalitetsgranskning No. 11). Stockholm: School Inspectorate.

Sharma, U., Forlin, C., \& Loreman, T. (2008). Impact of training on preservice teachers' attitudes and concerns about inclusive education and sentiments about persons with disabilities. Disability \& Society, 23(7), 773-785.

Shattuck, P., Narendorf, S., Cooper, B., Sterzing, P., Wagner, M., \& Taylor, J. (2012). Postsecondary education and employment among youth with an autism spectrum disorder. Pediatrics, 129(6), 1042-1049.

Sherif, M., \& Sherif, C. (1956). An outline on social psychology. New York: Harper.

Shevlin, M., Winter, E., \& Flynn, P. (2013). Developing inclusive practice: Teacher perceptions of opportunities and constraints in the republic of Ireland. International Journal of Inclusive Education, 17(10), 11191133. doi:10.1080/13603116.2012.742143

Silver, R., Measelle, J., Armstrong, J., \& Essex, M. (2005). Trajectories of classroom externalizing behavior: Contributions of child characteristics, family characteristics, and the teacher-child relationship during the school transition. Journal of School Psychology, 43, 39-60.

Simonoff, E., Pickles, A., Charman, T., Chandler, S., Loucas, T., \& Baird, G. (2008). Psychiatric disorders in children with autism spectrum disorders: Prevalence, comorbidity, and associated factors in a population-derived sample. Child Adolescence Psychiatry, 47(8), 921-929.

Skidmore, D. (2004). Inclusion the dynamics of school development. Glasgow: Open University Press.

Slee, R. (2006). Critical analyses of inclusive education policy: An international survey. International Journal of Inclusive Education, 10, 105-107.

Smith, A., \& Green, A. (2004). Including pupils with educational needs in secondary school physical education: A sociological analysis of teachers' views. British Journal of Sociology of Education, 25(5), 593-607.

SNAE (Swedish National Agency for Education). (2007). Behov av tydligare reglering av särskilt stöd och elevinflytande. ( No. 472). Stockholm: Skolverket.

SNAE (Swedish National Agency for Education). (2008). Rätten till utbildning - om elever som inte går i skolan [the right to education students who don't attend school]. (No. 334). Stockholm: Swedish National Agency for Education. 
SNAE (Swedish National Agency for Education). (2009). Skolan och aspergers syndrom. erfarenheter från skolpersonal och forskare. [school and Asperger syndrome. experiences of school staff and researchers] rapport nr: 334. Stockholm, Sweden: Skolverket.

Solé, R., Corominas-Murtra, B., Valverde, S., \& Steels, L. (2010). Language networks: Their structure, function and evolution. Complexity, 15(6), 2026.

Soles, T., Bloom, E. L., Heath, N. L., \& Karagiannakis, A. (2008). An exploration of teachers' current perceptions of children with emotional and behavioural difficulties. Emotional and Behavioural Difficulties, 13(4), 275-290.

SOU 1999:63.Att lära och leda. en lärarutbildning för samverkan och utveckling. [to learn and lead. A teacher education for cooperation and development]. Stockholm: Ministry of Education.

Sousa, C. P. (2011). The teacher's work. In M. Chib, B. Danermark \& S. Selander (Eds.), Education, professionalization and representations: On the transformation of social knowledge (pp. 68-74) Routledge.

Spurgeon, W. (2007). Diversity and choice for children with complex needs. In R. Cigman (Ed.), Included or excluded? The challenge of the mainstream for some SEN children. London: Routledge.

Starr, E., \& Foy, J. (2012). In parents' voices: The education of children with autism spectrum disorders. Remedial and Special Education, 33(4), 207216.

Swedish Educational Act 2010:800. [Skollag 2010:800]

Swedish Associaton for Autism and Asperger Syndrome. (2007). Autism- och aspergerförbundets undersökning om skolfrånvaro. An exploration of absenteeism by the Swedish association for autism and Asperger syndrome. Stockholm: The Swedish Association for Autism and Asperger Syndrome.

Symes, W., \& Humphrey, N. (2011). School factors that facilitate or hinder the ability of teaching assistants to effectively support pupils with autism spectrum disorders (ASDs) in mainstream secondary schools. Journal of Research in Special Educational Needs, 11(3), 153-161.

Syriopoulou-Delli, C., Cassimos, D., Tripsianis, G., \& Polychronopoulou, S. (2012). Teachers' perceptions regarding the management of children with autism spectrum disorder. Journal of Autism and Developmental Disorders, 42(5), 755-768.

Takala, M., Pirttimaa,R., \& Törmänen, M. (2009). Inclusive special education: The role of special education teachers in Finland.36, no. 3: 162-73. British Journal of Special Education, 36(3), 162-173. 
Takala, M., \& Astrid, A. (2014). Special education in Swedish and Finnish schools: Seeing the forest or the trees? British Journal of Special Education, 412(1), 59-81.

Takala, M., Hausstätter, R., Ahl, A., \& Head, G. (2012). Inclusion seen by student teachers in special education - differences among Finnish, Norwegian and Swedish students. European Journal of Teacher Education, 35(3), 305-325.

Thomas, G., \& Loxley, A. (2007). Deconstructing special education and constructing inclusion. Buckingham: Open University Press.

Tsai, L., \& Ghaziuddin, M. (2014). DSM-5 ASD moves forward into the past . Journal of Autism and Developmental Disorders, 44(2), 321-333.

Tversky, A., \& Kahneman, D. (1981). The framing of decisions and the psychology of choice. Science, 211, 453-458.

UNESCO. (1994). Salamanca statement and framework for action- on special needs education.

Vislie, L. (2003). From integration to inclusion: Focusing global trends and changes in the western European societies. European Journal of Special Needs Education, 18(1), 17-35.

Voelklein, C. \& Howarth, C. (2005). A review of controversies about Social representation theory: a British debate. Culture and psychology, 11(4) 431- 454.

Wachelke, J. (2008). Relationship between response evocation rank in social representations associtive tasks and personal symbolic value. Revue Internationale De Psychologie Sociale, 3(21), 113-126.

Wachelke, J., \& Wolter, R. (2011). Critera for construction and report of prototypical analysis for social representations. Psicologia Teoria E Pesquisa, 27(4), 521-526.

Wachelke, J. (2012). Social representation. A review of theory and research from a structural approach. Universitas Psychologica, 11(3)

Wagner, W. (1993). Can representation explain social behavior? A discussion of social representations as rational systems. Papers on Social Representations, 2(3), 236-249.

Wagner, W., Duveen, G., Farr, R., Jovchelovitch, S., Lorenzo-Cioldi, F., Marková, I., \& Rose, D. (1999). Theory and method of social representations. Asian Journal of Social Psychology, 2, 95-125.

Warnock, M. (2005). Special educational needs: A new outlook. London: Philosophy of Education Society of Great Britain.

Wehman, P., Schall, C., McDonough, J., Kregel, J., \& Brooke, V. (2014). Comparative employment for youth with autism spectrum disorders: Early results from randomized clinical trials. Journal of Autism and Developmental Disabilities, 44, 487-500. 
Wehmeyer, M. L., \& Rousso, H. (2006). Achieving equity: Disability and gender. In C. Skelton, B. Francis \& L. Smulyan (Eds.) The Sage handbook of gender and education (pp. 392-406). Thousand Oaks, CA US: Sage Publications, Inc.

Weinstein, R., Marshall, H., Sharp, L., \& Botkin, M. (1987). Pygmalion and the student: Age and classroom differences in children's awareness of teacher expectations. Child Development, 58(4), 1079-1093.

Westling Allodi, M. (2007). Equal opportunities in educational systems: The case of Sweden. European Journal of Education, 42(1)

Whannell, R., \& Allen, W. (2011). High school dropouts returning to study: The influence of the teacher and family during secondary school. Australian Journal of Teacher Education, 36(9), 22-35.

Wiles, A., Doderer, M., Ruan, J., Gu, T., Ravi, D., \& Blackman, B. (2010). Building and analyzing protein interactome networks by cross-species comparisons. BMC Systems Biology, 4(36)

Wilson, M., \& Scior, K. (2014). Attitudes towards individuals with disabilities as measured by the implicit association test: A literature review. Research in Developmnetal Disabilities., 35(2), 294-321.

Wing, L. (1981). Asperger's syndrome: A clinical account. Psychological Medicine, 11, 115-129.

Wismath, S. L., \& Zhong, M. (2014). Gender differences in university students' perception of and confidence in problem-solving abilities. Journal of Women and Minorities in Science and Engineering, 1-10.

WMA (World Medical Association). (2013). World medical association declaration of Helsinki: Ethical principles for medical research involving human subjects. The Journal of American Medical Association, 310(20)

Woodcock, S. \& Vialle, W. (2011). Are we exacerbating students' learning disabilities? An investigation of pre-service teachers' attributions of the educational outcomes of students with learning disabilities. Annals of Dyslexia, 61(2), 223-241. 



\section{Papers}

The articles associated with this thesis have been removed for copyright reasons. For more details about these see:

http://urn.kb.se/resolve?urn=urn:nbn:se:liu:diva-121062 


\section{Studies from the Swedish Institute for Disability Research}

1. Varieties of reading disability

Stefan Gustafson

ISBN 91-7219-867-2, 2000

2. Cognitive functions in drivers with brain injury - anticipation and adaptation

Anna Lundqvist

ISBN 91-7219-967-9, 2001

3. Cognitive deafness

Ulf Andersson

ISBN 91-7373-029-7, 2001

4. Att lära sig leva med förvärvad hörselnedsättning sett ur par-perspektiv

Carin Fredriksson

ISBN 91-7373-105-6, 2001

5. Signs, Symptoms, and Disability Related to the Musculo-Skeletal System

Gunnar Lundberg

ISBN 91-7373-160-9, 2002

6. Participation - Ideology and Everyday Life

Anette Kjellberg

ISBN 91-7373-371-7, 2002

7. Föräldrar med funktionshinder - om barn, föräldraskap och familjeliv

Marie Gustavsson Holmström

ISBN 91-7203-500-5, 2002

8. Active wheelchair use in daily life

Kersti Samuelsson

ISBN 91-7373-196-X, 2002

9. Två kön eller inget alls. Politiska intentioner och vardagslivets realiteter $\mathbf{i}$ den arbetslivsinriktade rehabiliteringen

Marie Jansson

ISBN 91-7373-568-X, 2003 
10. Audiological and cognitive long-term sequelae from closed head injury Per-Olof Bergemalm

ISBN 91-7668-384-2, 2004

11. Att vara i särklass - om delaktighet och utanförskap i gymnasiesärskolan Martin Molin

ISBN 91-85295-46-9, 2004

12. Rättvis idrottsundervisning för elever med rörelsehinder - dilemma kring omfördelning och erkännande

Kajsa Jerlinder

Licentiate Degree, 2005

13. Hearing impairment and deafness. Genetic and environmental factors interactions - consequences. A clinical audiological approach

Per-Inge Carlsson

ISBN 91-7668-426-1, 2005

14. Hearing and cognition in speech comprehension. Methods and applications Mathias Hällgren

ISBN 91-85297-93-3, 2005

15. Living with deteriorating and hereditary disease: experiences over ten years of persons with muscular dystrophy and their next of kin

Katrin Boström

ISBN 91-7668-427-x, 2005

16. Disease and disability in early rheumatoid arthritis

Ingrid Thyberg

ISBN 91-85299-16-2, 2005

17. "Varför får jag icke följa med dit fram?" Medborgarskapet och den offentliga debatten om dövstumma och blinda 1860-1914

Staffan Bengtsson

ISBN 91-85457-06-X, 2005

18. Modalities of Mind. Modality-specific and nonmodality-specific aspects of working memory for sign and speech

Mary Rudner

ISBN 91-85457-10-8, 2005 
19. Facing the Illusion Piece by Piece. Face recognition for persons with learning disability

Henrik Danielsson

ISBN 91-85497-09-6, 2006

20. Vuxna med förvärvad traumatisk hjärnskada - omställningsprocesser och konsekvenser i vardagslivet. En studie av femton personers upplevelser och erfarenheter av att leva med förvärvad traumatisk hjärnskada

Thomas Strandberg

ISBN 91-7668-498-9, 2006

21. Nycklar till kommunikation. Kommunikation mellan vuxna personer med grav förvärvad hjärnskada och personernas närstående, anhöriga och personal

Pia Käcker

ISBN 978-91-85715-88-6, 2007

22. ”Aspergern, det är jag”. En intervjustudie om att leva med Asperger syndrom Gunvor Larsson Abbad

ISBN 978-91-85831-43-2, 2007

23. Sounds of silence - Phonological awareness and written language in children with and without speech

Janna Ferreira

ISBN 978-91-85895-74-8, 2007

24. Postponed Plans: Prospective Memory and Intellectual Disability

Anna Levén

ISBN 978-91-85895-57-1, 2007

25. Consequences of brain tumours from the perspective of the patients and of their next of kin

Tanja Edvardsson

ISBN 978-91-7668-572-3, 2008

26. Impact on participation and service for persons with deafblindness

Kerstin Möller

ISBN 978-91-7668-595-2, 2008

27. Approaches to Audiological Rehabilitation with Hearing Aids: studies on prefitting strategies and assessment of outcomes

Marie Öberg

ISBN 978-91-7393-828-0, 2008 
28. Social Interaction and Participation in Activities of Everyday Life Among Persons with Schizophrenia

Maria Yilmaz

Licentiate Degree, 2009

29. Focus on Chronic Disease through Different Lenses of Expertise

Towards Implementation of Patient-Focused

Decision Support Preventing Disability:

The example of Early Rheumatoid Arthritis

Örjan Dahlström

ISBN 978-91-7393-613-2, 2009

30. Children with Cochlear Implants: Cognition and Reading Ability

Malin Wass

ISBN: 978-91-7393-487-9, 2009

31. Restricted participation:

Unaccompanied children in interpreter-mediated asylum hearings in Sweden

Olga Keselman

ISBN: 978-91-7393-499-2, 2009

32. Deaf people and labour market in Sweden.

Education - Employment - Economy

Emelie Rydberg

ISBN: 978-91-7668-725-3, 2010

33. Social rättvisa i inkluderande idrottsundervisning

för elever med rörelsehinder - en utopi?

Kajsa Jerlinder

ISBN: 978-91-7668-726-0, 2010

34. Erfarenheter av rehabiliteringsprocessen mot ett arbetsliv

- brukarens och de professionellas perspektiv

Helene Hillborg

ISBN: 978-91-7668-741-3, 2010

35. Knowing me, knowing you - Mentalization abilities of children who use augmentative and alternative communication

Annette Sundqvist

ISBN: 978-91-7393-316-2, 2010 
36. Lärare, socialsekreterare och barn som far illa - om sociala representationer och interprofessionell samverkan

Per Germundsson

ISBN: 978-91-7668-787-1, 2011

37. Fats in Mind

Effects of Omega-3 Fatty Acids on Cognition and Behaviour in Childhood

Ulrika Birberg Thornberg

ISBN: 978-91-7393-164-9, 2011

38. "Jobbet är kommunikation”

Om användning av arbetshjälpmedel för personer med hörselnedsättning

Sif Bjarnason

Licentiate Degree. ISBN: 978-91-7668-835-9, 2011

39. Applying the ICF-CY to identify everyday life situations of children and youth with disabilities

Margareta Adolfsson

ISBN: 978-91-628-8342-3, 2011

40. Tinnitus - an acceptance-based approach

Vendela Zetterqvist

ISBN: 978-91-7393-040-6, 2011

41. Applicability of the ICF-CY to describe functioning and environment of children with disabilities

Nina Klang

ISBN: 978-91-7668-864-9, 2012

42. Bringing more to participation

Participation in school activities of persons with Disability within the framework of the International Classification of Functioning, Disability and Health for Children and Youth (ICF-CY)

Gregor Maxwell

ISBN: 978-91-628-8484-0, 2012

43. From Eye to Us.

Prerequisites for and levels of participation in mainstream school of persons with Autism Spectrum Conditions

Marita Falkmer

ISBN: 978-91-637-2091-8, 2013 
44. Otosclerosis, clinical long-term perspectives

Ylva Dahlin-Redfors

ISBN 978-91-628-8617-2, 2013

45. Tinnitus in Context - A Contemporary Contextual Behavioral Approach

Hugo Hesser

ISBN 978-91-7519-701-2, 2013

46. Hearing and middle ear status in children and young adults with cleft palate Traci Flynn

ISBN 978-91-628-8645-5, 2013

47. Utrymme för deltagande, beslutsprocesser i möten mellan patienter med ospecifika ländryggsbesvär och sjukgymnaster i primär vård

Iréne Josephson

ISBN 42-978-91-85835-41-6, 2013

48. "Man vill ju klara sig själv” Studievardagen för studenter med Asperger syndrom i högre studier

Ann Simmeborn Fleischer

ISBN 978-91-628-8681-3, 2013

49. Cognitive erosion and its implications in Alzheimer's disease

Selina Mårdh

ISBN 978-91-7519-621-1, 2013

50. Hörselscreening av en population med utvecklingsstörning

Utvärdering av psykoakustisk testmetod och av OAE-registrering som

komplementär metod

Eva Andersson

Licentiate Degree. ISBN 978-91-7519-616-9, 2013

51. Skolformens komplexitet - elevers erfarenheter av skolvardag och tillhörighet i gymnasiesärskolan

Therése Mineur

ISBN 978-91-7668-951-6, 2013

52. Evaluating the process of change:

Studies on patient journey, hearing disability acceptance and stages-of-change

Vinaya Kumar Channapatna Manchaiah

ISBN 978-91-7519-534-6, 2013 
53. Cognition in hearing aid users: Memory for everyday speech

Hoi Ning (Elaine) Ng

ISBN 978-91-7519-494-3, 2013

54. Representing sounds and spellings Phonological decline and compensatory working memory in acquired hearing impairment

Elisabet Classon

ISBN 978-91-7519-500-1, 2013

55. Assessment of participation in people with a mild intellectual disability

Patrik Arvidsson

ISBN 978-91-7668-974-5, 2013

56. Barnperspektiv i barnavårdsutredningar - med barns hälsa och barns upplevelser i fokus

Elin Hultman

ISBN 978-91-7519-457-8, 2013

57. Internet Interventions for Hearing Loss

Examining rehabilitation Self-report measures and Internet use in hearing-aid users

Elisabet Sundewall Thorén

ISBN 978-91-7519-423-3, 2014

58. Exploring Cognitive Spare Capacity: Executive Processing of Degraded Speech Sushmit Mishra

ISBN 978-91-7519-386-1, 2014

59. Supported employment i en svensk kontext - förutsättningar när personer med funktionsnedsättning når, får och behåller ett arbete

Johanna Gustafsson

ISBN 978-91-7529-012-6, 2014

60. Effects of Specific Cochlear Pathologies on the Auditory Functions:

Modelling, Simulations and Clinical Implications

Amin Saremi

ISBN 978-91-7519-365-6, 2014 
61. Children with profound intellectual and multiple disabilities and their participation in family activities

Anna Karin Axelsson

ISBN 978-91-85835-48-5, 2014

62. Lexical and Semantic Development in Children With Cochlear Implants

Ulrika Löfkvist

ISBN 978-91-7549-546-0, 2014

63. Rethinking sound. Computer-assisted reading intervention with a phonics approach for deaf and hard of hearing children using cochlear implants or hearing aids

Cecilia Nakeva von Mentzer

ISBN 978-91-7519-270-3, 2014

64. Assessing cognitive spare capacity as a measure of listening effort using the Auditory Inference Span Test

Niklas Rönnberg

ISBN 978-91-7519-267-3, 2014

65. Employees with Aided Hearing Impairment: An Interdisciplinary Perspective Håkan Hua

ISBN 978-91-7519-240-6, 2014

66. Prosthetic and Orthotic Services in Developing Countries

Lina Magnusson

ISBN 978-91-85835-55-3, 2014

67. Dealing with digits - Arithmetic, memory and phonology in deaf signers Josefine Andin

ISBN: 978-91-7519-235-2, 2014

68. Time is of the essence in speech recognition: Get it fast or think about it Shahram Moradi

ISBN: 978-91-7519-188-1, 2014

69. Effects of hearing loss on traffic safety and mobility Aspekter på lärande vid dövblindhet

Birgitta Thorslund

ISBN: 978-91-7519-178-2, 2014 
70. Aspekter på lärande vid dövblindhet - möjligheter och begränsningar för personer med Alström syndrom

Berit Rönnåsen

Licentiate Degree. ISBN: 978-91-7529-068-3, 2015

71. Memory and communication in typically developing infants and children with Autism Spectrum Disorder: Behavioral and electrophysiological indices

Emelie Nordqvist

ISBN: 978-91-7519-078-5, 2015

72. Cognitive capacities and composite cognitive skills in individuals with Usher syndrome type 1 and 2

Cecilia Henricson

ISBN: 978-91-7685-999-5, 2015

73. Functioning and Disability in Adults with Hearing Loss

Preparatory studies in the ICF Core Sets for Hearing Loss project

Sarah Granberg

ISBN: 978-91-7529-086-7, 2015

74. Speech recognition and memory processes in native and non-native language perception

Lisa Kilman

ISBN: 978-91-7685-972-8, 2015 